\title{
Understanding barriers and challenges to effective community participation in the rollout of HIV/AIDS treatment and care services: Report on research results dissemination meetings
}

Population Council

Health Systems Trust

Follow this and additional works at: https://knowledgecommons.popcouncil.org/departments_sbsr-hiv

Part of the Family, Life Course, and Society Commons, Gender and Sexuality Commons, and the International Public Health Commons

How does access to this work benefit you? Let us know!

\section{Recommended Citation}

Population Council and Health Systems Trust. 2006. "Understanding barriers and challenges to effective community participation in the rollout of HIV/AIDS treatment and care services: Report on research results dissemination meetings." Johannesburg: Population Council. 


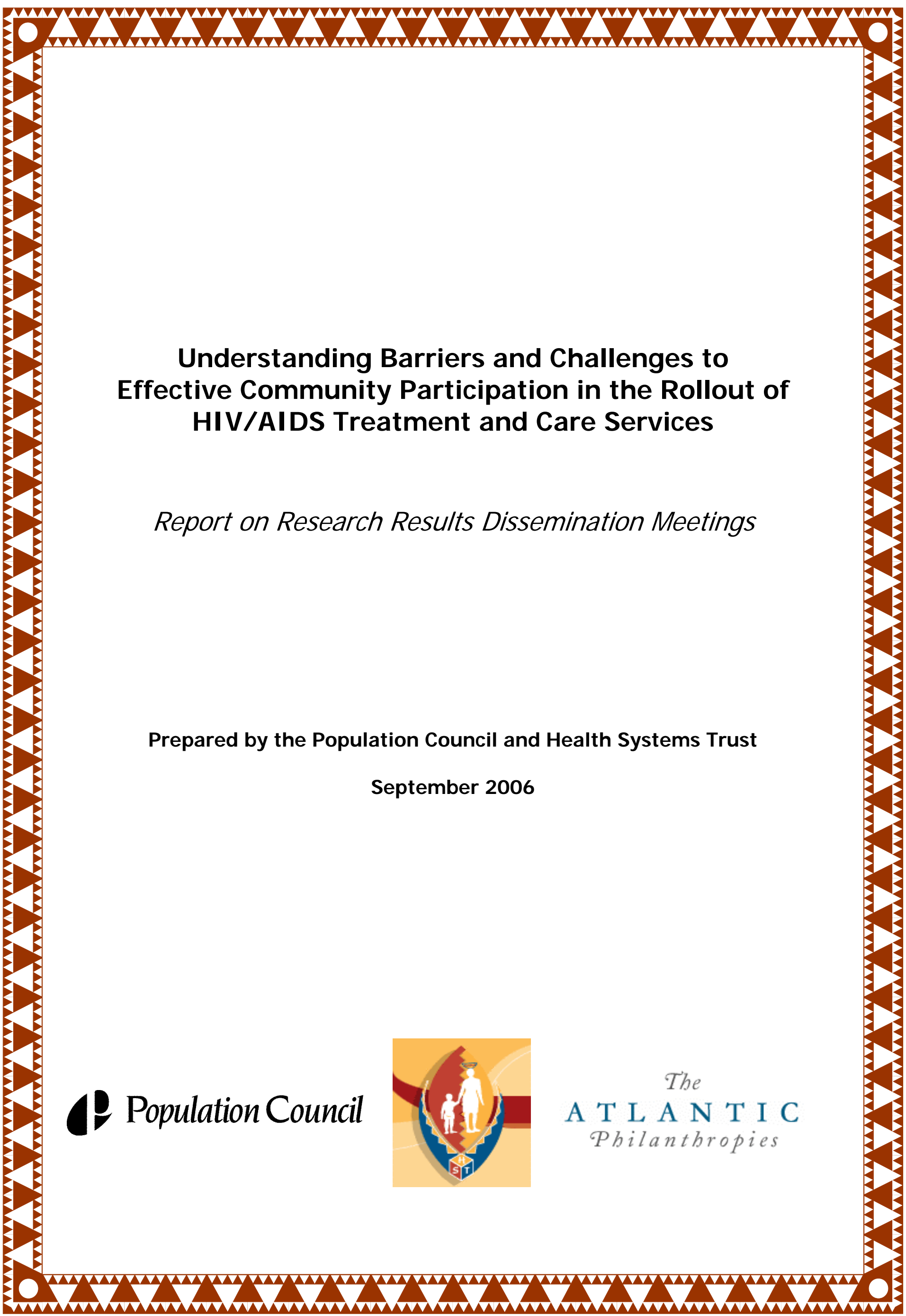



1 Population Council The Population Council is an international, non-profit, nongovernmental current and future generations around the world and to help achieve a humane, equitable, and sustainable balance between people and resources. The Council conducts biomedical, social science, and public health research and helps build research capacities in developing countries. Established in 1952, the Council is governed by an international board of trustees. Its New York headquarters supports a global network of country offices.

Published in September 2006.

Copyright 2006 The Population Council Inc.

Suggested citation: Population Council and Health Systems Trust. 2006. "Understanding barriers to community participation in HIV and AIDS services: Report on research results dissemination meetings.” Johannesburg: Population Council.

This document may be reproduced in whole or in part without permission of the Population Council provided full source citation is given and the reproduction is not for commercial purposes. 


\section{Table of Contents}

$\begin{array}{ll}\text { Overview } & 1\end{array}$

$\begin{array}{ll}\text { Community Dissemination Meetings } & 1\end{array}$

Introduction 1

Research presentations 2

Discussion and recommendations 2

Conclusion 3

Provincial Dissemination Meetings $\quad 4$

Introduction 4

Workshop feedback 5

Discussion and recommendations $\quad 5$

National Dissemination and Strategy Development Meeting - Johannesburg 8

Introduction

$\begin{array}{lr}\text { Research presentations } & 9\end{array}$

Identification of key issues $\quad 10$

Group sessions: Strategy development 11

$\begin{array}{ll}\text { Appendices } & 15\end{array}$

$\begin{array}{ll}\text { Appendix 1: List of participants } & 15\end{array}$

Appendix 2: Participants' feedback report 23

Appendix 3: Presentations 26 


\section{Overview}

The Population Council (PC), in partnership with the Health Systems Trust (HST) conducted one national, two provincial, and seven community dissemination meetings between February and August 2006 in KwaZulu Natal (KZN), Limpopo and Gauteng provinces. The purpose of these meetings was to share results from the research study: "Understanding barriers and challenges to effective community participation in the rollout of HIV/AIDS treatment and care services" conducted in KZN and Limpopo provinces in 2005. Over 350 people attended the dissemination meetings, representing various government and non-governmental organizations (NGOs). For a complete participant list, see Appendix 1.

The main objectives of the dissemination meetings were to:

- Share the research findings with the communities and organizations that participated in the study.

- Solicit participants' input in understanding and utilizing the research findings.

- Facilitate interaction and exchange between different stakeholders including community and facility-based providers involved in ART services.

- Develop key strategies to operationalize findings and for the development of appropriate interventions and activities.

- Promote the use of the study findings to inform policy decisions and program priorities at the community, provincial, and national levels.

This report complements the full and summary research reports of the study titled, Understanding barriers to community participation in HIV and AIDS. It highlights the main issues raised by participants and offers suggestions for utilizing the research results and priorities for follow-on activities and interventions.

The report is divided into three sections. The first section focuses on the community dissemination meetings in Maphumulo and Chesterville (KZN) and Seshego and Phukhukhune (Limpopo); the second section covers the provincial dissemination meetings in Durban and Polokwane, and the third focuses on the National Strategy Development Meeting held in Johannesburg.

\section{Community Dissemination Meetings}

\section{Introduction}

Over 200 people took part in seven community dissemination meetings, which were held in Chesterville and Maphumulo in KZN and Seshego and Phukhukhune in Limpopo in February and March 2006. Participants included facility-based health care workers, community health workers, traditional healers, clinic committee members, local NGOs and community-based organizations (CBOs), traditional leaders/chiefs [Induna], community leaders, church leaders, and people from different community groups working on HIV and AIDS. These workshops included individuals who took part in the study as well as those with an interest in the research findings.

Letters of invitation were sent out to all relevant organizations, as well as to individual community members. Clinic staff and clinic committee members were involved in identifying 
suitable participants for the meetings. Notices were placed at clinic premises to inform the community about the workshops.

There was a high level of enthusiasm by participants, nearly all of who were attending a research dissemination meeting for the first time. They expressed appreciation that the results of research conducted in their communities were being discussed with them. It was noteworthy that although these community members were not familiar with feedback meetings, they remarked that after participating in other studies conducted in their communities, they were never told about the outcomes. There was initial concern by the organizers that there would be a low turnout at the meetings because HIV and AIDS stigma was still a major challenge, particularly in Chesterville, where high levels of stigma surrounding HIV and AIDS was reported. However, the meetings were well attended.

\section{Research presentations}

Research findings were presented using flipcharts to make it participatory and practical. The meetings were conducted in the local languages: Northern Sotho in Limpopo and Zulu in KZN. The presentations covered key findings including:

1. HIV and AIDS denial.

2. Discrimination and stigma.

3. Services and service providers.

4. Access to antiretrovirals (ARVs).

5. Experiences of people on ARVs.

6. NGO involvement in ARV services.

Participant input was solicited through discussion sessions. These sessions explored the results presented and sought participant feedback on how best to tackle challenges relating to HIV and AIDS at the community level, including how communities and ARV facilities should work together.

\section{Discussion and recommendations}

After the presentations were made, participants were given an opportunity to ask questions. Most of the questions raised concerned the sampling of sites. Participants were interested in knowing why some areas were not included in the study. The sampling method was then explained to them. Participants were then divided into groups to discuss the results and make recommendations. The following recommendations were made:

\section{Feedback from Seshego, Polokwane and Phokwane, Sekhukhune (Limpopo Province)}

- Municipalities need to be involved in mentoring HIV and AIDS organizations. An example was cited in Polokwane where the municipality is successfully mentoring Takalani Nana, an organization that is providing psychosocial support for people living with HIV and AIDS.

- More counsellors and educators need to be trained to reach out to community members, including those living with HIV. Specifically, an intensive community-based program needs to be designed that involves NGOs and CBOs, where counsellors and educators would create awareness on positive attitudes towards people living with HIV and AIDS. 
- There is a need to promote regular distribution of food parcels to address the nutritional problems of people living with HIV and AIDS. The issue of gardening was raised as a sustainable strategy to address the nutritional needs of the community at-large, in addition to people living with HIV and AIDS.

- Intensive campaigns on issues related to voluntary counselling and testing (VCT) promotion, including prevention of mother to child transmission (PMTCT). An effective coordination system for greater awareness and use of services was stressed.

- In addition to the current traditional healers' training program in the province (traditional healers are trained on how to treat patients, including referral to health facilities for further assessment), more traditional healers should be trained through the Traditional Healers Organization and through Takalani Nana. This would forge better cooperation between clinics, hospitals, and traditional healers.

- It is crucial to educate the community about what the roles of home-based caregivers, NGOs, and CBOs are, and what services they provide to increase their acceptance and support for the work they are doing.

- Clinic committee members should expand their focus and to do more outreach programs reaching schools and teaching youth about HIV and ARVs.

- The current legislation was perceived as promoting stigmatization of HIV and AIDS due to confidentiality clauses and the secrecy it promotes around the disease. The meeting highlighted that HIV and AIDS should be treated like any other chronic disease such as diabetes, asthma, hypertension, mental illness, and so on.

\section{Feedback from Chesterville and Maphumulo (KZN)}

- There is a need to involve FBOs in HIV and AIDS issues, as they could play a major role in terms of providing support services, encouraging people to use counselling and testing services, and promoting disclosure.

- People do not want to participate in HIV and AIDS events and activities because of the fear of being discriminated against by their families and the entire community. It was recommended that community structures such as traditional leaders' organizations, CBOs, churches and traditional healers encourage and support community members to participate effectively in such activities.

- Since traditional leaders/chiefs [induna/inkosi] play significant roles and are influential in their communities, they need to play a key role in community discussions around HIV and AIDS and should regularly include these topics in discussions during their meetings. These leaders also need to be trained on HIV and AIDS so that they can develop the confidence to speak openly on the subject. They should actively encourage people to use counselling and testing services and promote support for those affected by HIV and AIDS.

- Antiretroviral therapy (ART) facility staff should give more information to community health workers and capacitate them so they can provide and facilitate activities to promote greater community access to ART services.

\section{Conclusion}

Community participation in the provision of ART services is considered crucial to the success of the national rollout program. However, for this to be effective, health facilities need to formally support representatives of key community structures and organizations becoming an active part of the program. A practical step that can be taken includes 
establishing advisory groups whose members include community representatives, fully reflecting the diverse interests of different ethnic and cultural groups.

Overall, the community members, traditional healers, NGO/CBO representatives, clinic committee members, health workers, and community health workers who participated in the meetings said sharing the results of the research was very important to them and was very informative. It added a lot of value to their knowledge and would enable them improve the services they are providing to those affected by HIV and AIDS.

The community dissemination meetings provided the opportunity to promote communication between health facilities, traditional healers, community/traditional leaders, institutions and the community in general, something that is generally lacking in all of these communities.

\section{Provincial Dissemination Meetings}

\section{Introduction}

The first provincial dissemination meeting was held in Durban at the Royal Hotel on 8 August 2006. The meeting drew a number of people from the Department of Health (from the province and districts), Department of Social Development, NGOs, CBOs, health providers, and HIV/AIDS advocacy groups. A total of 48 participants attended. The Population Council's Regional Director, Dr. Ayo Ajayi, officially opened the meeting and welcomed participants. Dr. Petrida Ijumba, Deputy Director of HealthLink in the Health Systems Trust, made the opening speech. She highlighted some of the challenges that the AIDS epidemic is posing, not only in South Africa, but also in the southern region as a whole and provided some data on the current prevalence rates and the impacts of the epidemic.

Representing the Provincial Department of Health, Dr. M.S. Dlwati of the Edendale Hospital said that the results of the study conducted in KZN and Limpopo Provinces highlight some of the challenges facing health service provision and pinpoint ways of involving communities in HIV and AIDS and ARV services. He said that while the Department faces some challenges in the provision of health services, it has many successes which include improved access and quality of care, as well as the implementation of the Comprehensive Plan for HIV and AIDS prevention, treatment, care and support. He was optimistic that the research and discussions at the meeting would set the tone for the future of health care in KZN, taking into account the objectives of effectiveness and efficiency in the provision of quality, compassionate, and equitable health services.

The second provincial dissemination meeting, attended by a total of 58 participants, was held in Polokwane, Limpopo Province on 17 August 2006. Participants represented different CBOs, NGOs, traditional healers, health workers, clinic committees, and the Provincial Department of Health and Social Development's HIV and AIDS Unit. Dr. Eka Williams of the Population Council welcomed participants and provided a background on the research study and information on the dissemination activities which had already taken place. She introduced Dr. Pinini, who is the Director of the HIV/AIDS Unit for the Provincial Department of Health and Social Development, to make opening remarks and give an overview on the current state of HIV and AIDS in the province. 
In her opening remarks, Dr. Pinini provided an overview of the progress in the rollout of ARVs in the province and the prevalence of HIV. So far 28 sites have been accredited and about 7,000 people have been placed on treatment. She said that the Department stresses the need for people on treatment to also have access to good nutrition as well as emotional support. The Department also stresses the need for NGOs to be supported so they can assist patients and the importance of strengthening the healthcare system.

Dr. Pinini highlighted some of the major challenges faced by the province in the provision of treatment services, which include limited human resources and capacity of health facilities and inadequate collaboration and coordination between community structures and the government. The lack of adequate numbers of different types of health workers in public health system is a major challenge to providing ARVs to all people who need them and to enable the expansion of the province's treatment program. She expressed the interest of the Department to work closely with different CBOs, but said that it is sometimes difficult to obtain information on some groups especially those working in rural areas. She was positive that the meeting would provide the Department the opportunity to meet representatives of NGOs and CBOs and to learn about their work.

\section{Workshop feedback}

In both provincial dissemination meetings (as well as the National Strategy Meeting) the Population Council and Health System Trust presented the research findings in the form of PowerPoint presentations to the participants. The presentations covered all the key findings from the study and although these results were combined where necessary, comparisons and differences between the two provinces were identified and discussed. Also, feedback from the national strategy meeting held in Johannesburg in June was presented to participants. At the provincial meetings, a short evaluation form was handed to participants and the results were collated. (See evaluation results in Appendix 2 and Workshop presentation in Appendix 3).

\section{Discussion and recommendations}

Based on a list of specific questions posed to participants as well as general feedback on the research results and on-going local experience and activities, the following recommendations were made at the dissemination meeting in Durban.

\section{Main themes/areas Population Council should address}

- The National Association for People Living with AIDS (NAPWA) felt that many people still do not have access to ARVs, especially those in the rural areas. The speaker highlighted that centralization of treatment is still a problem, as a result many people in rural areas are not receiving ARVs but opt for traditional medicines, which they have access to. Nutrition was also indicated as a major challenge. The speaker recommended that there should be some form of balance between nutritional support and treatment.

- Traditional healers provide a significant proportion of health care services in communities and effective strategies to use them as an entry point to treatment and to support people on treatment need to be developed. A large proportion of people in the province strongly believe in traditional medicine and that traditional healers are the highly respected. A lot of discussion addressed "ÜBHEJANE", a well known and accepted traditional medicine believed to be an immune booster and beneficial for people with HIV and AIDS. It was 
recommended that a referral system between traditional healers and the health facilities be developed. It was also recommended that traditional headers receive adequate training on HIV, AIDS, and STIs.

- There is a need to encourage organizations providing community services to collaborate and work together instead of competing. It was recommended that the capacity of these organizations be promoted and strengthened, and that it include training in monitoring and evaluation. Coalitions of civil society organizations should be established to implement a coordinated response through a participatory and transparent process so that ordinary people can participate in a meaningful manner. Also, the issue of communities being disempowered by "experts" was raised. It was felt that often "experts" come from outside the community to work but do nothing to build the capacity of community members and organizations and sometimes assume the position of community spokespersons. Programs being brought into communities should ensure that the synergy and energy of community members as well as their experience and resources are enhanced. It was stressed that it was necessary to build on existing programs to provide the community a sense of ownership and to enhance their leadership in program implementation. Several local experiences were discussed, including work by HIVAN, which is aimed at facilitating partnership between different stakeholders through periodic community-held meetings.

- The participants recommended that a memorandum of understanding be established between the main community actors involved in treatment activities and government, and that the government accredit NGOs and CBOs to ensure standards and quality. The example of Sinosizo, a local NGO was discussed. This organization is working with the government and has signed an MOU delineating what type of treatment services it provides as well as responsibilities and guidelines for providing treatment related services.

- It was recommended that some form of financial support for home-based care

- programs be developed, as most programs fail due to a lack of financial support.

- There is a need for a coordinated approach from different government departments, not only the Department of Health, and for mechanisms to be put in place to expand the number of government departments with key roles in the provision of treatment related services.

- A huge gap was identified between what is rhetoric and what is happening on the ground. The participants suggested that there is a need to consolidate ideas from different actors and to come up with more practical and achievable targets and proper systems to monitor what is happening on the ground. There is a need for better accountability from all stakeholders.

\section{Partners the Population Council should work with}

- The participants highlighted that the Council should work hand-in-hand with a wide range of organizations with strong roots in the community programming, and enhance their capacity to successfully implement and monitor relevant programs.

\section{Main outcomes expected in two years}

- An increase in the number of step-down facilities such as that run by Sinosizo to help address the inadequacy of available services, heavy workload of health providers, and to expand access to follow-up services for people on treatment.

- A major contribution toward destigmatizing HIV and AIDS so that it is treated like any other chronic disease. 
- Strengthened social support services for people who are infected and with affected by HIV and AIDS. This includes functional and continual referral systems to reduce loss to follow-up.

- More people in the communities trained as volunteers and community-based services engaged.

- Exploration of "social medical models", such as that implemented by Valley Trust, to address the "medicalization" of the HIV and AIDS response and promote stronger community participation and ownership.

The priority themes identified for interventions in KZN include the following:

1. ARVs and nutrition: Increasing access to good nutrition for those who are on ARVs and ensuring that HIV-infected people who are not on ARVs have access to good nutrition to prolong god health in order to delay onset of treatment.

2. Traditional healers: Strengthening the role of traditional healers, particularly to facilitate access to ARVs and to support treatment adherence.

3. Empowerment of community structures to become leading players in the expansion of treatment programs. Related to this is the need to establish/strengthen networks and partnerships focussing on treatment.

4. Expanding treatment interventions to address other programs such as those dealing with orphans and vulnerable children (OVC), which will bring the Department of Social Development and other departments to become primary partners in treatment.

The following recommendations were made at the dissemination meeting in Polokwane.

\section{Main themes/areas Population Council should address}

- The ART program is currently dominated and led by the Department of Health. Other government departments, such as the Agriculture, Home Affairs, Water Affairs, are not visible. Participants recommended engaging other government departments, and not look at HIV as a health problem only. The private sector has also been sponsoring some of the programs and needs to be better involved. It should be recognized that in each government department there is an HIV/AIDS program. The only departments that have been visible are Health/Social Development and Education. (Note that in Limpopo, the Department of Health and the Department of Social Development are one department called the Department of Health and Social Development.)

- There is a need to develop strategies to link OVC with treatment, care and support services. Many OVC are currently underserved or not being reached with any services due to numerous reasons, especially OVC in rural areas. In terms of the caregivers, support for those caring for OVC should be given high priority. They are currently a neglected subpopulation of caregivers.

- People with disabilities also need support, as they are unable to access some of these services. Their HIV and AIDS related needs should be addressed.

- Many caregivers lack the skills and the resources to adequately provide care; this needs to be taken into serious consideration. Caregivers need to be armed with the right information about all aspects of HIV and AIDS from prevention to care and treatment.

- Interventions for disclosure were highlighted. There is a need to work closely with those people who are open about their status to make other people feel comfortable to talk about the disease and disclosure.

- People with HIV need to be prepared before they are started on ARVs to ensure good adherence and treatment outcomes. The GIPA (greater involvement of people living with HIV/AIDS) concept should be applied to treatment programs. 
- The importance of proper education for everyone on treatment was highlighted. The Treatment Action Campaign (TAC) shared their experience on treatment education, and said that people on treatment and their families should be educated about what they should expect when treatment is started and afterwards. Information provided in this way can be shared with community members to keep the community as a whole better informed.

- Strengthening of referral systems from the community to the health facilities should be given high priority to ensure treatment success. Further, there is a need to strengthen the focus on rural access to treatment and related HIV and AIDS services.

- The province of Limpopo neighbours with Mozambique and Zimbabwe and as a result there is an influx from these border areas into the province for treatment. This is creating a big challenge, especially following-up patients in terms of adherence.

- Due to the capacity problems facing the province, the Department is unable to cover all those who need treatment. Interventions to keep HIV infected people healthy (physically and emotionally) are required as the Department continues to address capacity needs for the treatment program.

\section{Partners Population Council should work with}

- Amakhosi-traditional leaders who can play a great role in treatment access and support.

- Educators/school governing bodies, to reach young people.

- Taxi drivers are not involved in prevention or treatment issues, and men generally are not well reached.

\section{Main outcomes expected in two years}

- Increased level of adherence by people on ARVs. Anecdotes suggest there are many factors inhibiting proper adherence practices. Dr. Pinini expressed the interest of department in obtaining assistance from PC in addressing the potential problem of nonadherence to ARVs in the province.

- Interventions and support to ensure that more men and children are put on treatment in the province.

\section{National Dissemination and Strategy Development Meeting - Johannesburg}

\section{Introduction}

On 8 June 2006, Population Council and Health Systems Trust organized a national dissemination and strategy meeting at the Balalaika Hotel, Sandton. The meeting was aimed at understanding strategies for a more effective community participation in treatment to support the national treatment program as well as to share results of a research study conducted in KZN and Limpopo provinces. A total of 52 participants attended the meeting, representing 30 organizations and institutions. Dr. Ayo Ajayi of the Population Council welcomed participants. He gave an overview of the epidemic and also pointed out South Africa's rapidly growing ARV coverage. However, there still remains a gap in terms of those who need ARVs and those able to access treatment. He acknowledged the conflicts and tensions that face communities in terms of accessing treatment, including stigma and the role 
of traditional healers. He acknowledged support from AP, and Zola Madikela for facilitating the study in South Africa, and also the role of HST, which conducted the study.

\section{Research presentations}

Dr. Thiloshini Govender, of the KZN Department of Health provided an overview on community participation in ART rollout with a focus on the KZN experience. The most important objective of the KZN program is to improve the quality of life of infected and affected people. She stressed that the "medical model" of diagnosis, treatment and care is no longer a useful approach. It does not recognize the many conflicts individuals face, and is not geared towards empowering the individual. Fundamental issues such as jobs and food need to be considered when developing appropriate service delivery strategies. Also, pretending that traditional healers are not an important force is a wrong paradigm. Mapping is important to design appropriate programs.

The National Department of Social Development (NDoSD) was represented by Abram Phahlamohlaka. From the viewpoint of the NDoSD, he said that family is the first line of responsibility for HIV and AIDS care, and the community is the second line. The Department's policy for OVC stipulates the need for all sectors to coordinate toward a strengthened response. The Department is yet to articulate its role in the ARV rollout but it seems that there are a number of important entry points, including programs focussing on families and communities and those working on OVC issues.

The NDoSD strategies include:

- Strengthened support for OVC

- Sustainable food security development

- Training caregivers

- Strengthening community support and mobilization.

The NDoSD is open to collaboration, and to work with partners and communities to strengthen the national treatment program. Its participation in this meeting is part of its learning curve and to gain ideas for its potential work in this area.

Speaking on the "Road to Treatment," Pholokgolo Ramothwala of the Treatment Action Campaign, Limpopo said that the community, neighbours, household members are the first line of support for people living with HIV on ARVs because they are the first people to notice side effects, and other health problems one encounters, not the clinic staff. They need to be on board if treatment is to be effective and successful. With respect to support groups, perceptions about their use are not always positive. There is a need to ensure that support groups can deal with stigma and give the community quality information in order to counter stigma. Community groups and NGOs need to recognize the role of traditional healers and community leaders. For the road to treatment to be accessible and friendly, communities need more information, and individuals accessing treatment need to become more knowledgeable about ARVs. As the number of people needing treatment is growing, the burden and load may be overwhelming because communities have not been mobilized, prepared, and given a chance to participate effectively. 
Dr. Natalya Dinat of Wits University discussed concepts and practices around community participation. She raised several issues, and stressed that in the context of HIV and AIDS, we may need to ask if the people who live openly with HIV represent all people living with HIV.

Mr. Nkululeko Nxesi of the National Association of People Living with HIV and AIDS said that the study confirms previous research findings and stressed especially on findings indicating the persistence of inadequate services for women and youths. It is important to tackle poverty as an aspect of HIV. Also, programs must address stigma, especially in rural areas. Many issues including clarity about the role of traditional healers are bogging down community response. There is confusion about the roles of the different stakeholders. This is largely because of the lack of a coordinated response. The struggle between the formal and informal health systems needs to be tackled.

Dr. Farshid Meidany of MDCI, KZN stressed the need to add messages on ART and TB to current programs in such a way that these issues are well integrated, both in terms of messages and the services delivered. This is important for reaching out to and expanding participation at the community level. In terms of stigma, support groups are important. They are a strong link between services and CBOs. For people on treatment, support is required from their families, and friends, so there is a need for these people to be directly involved and capacitated to play this role.

\section{Identification of key issues}

Using a discussion and brainstorming approach, Prof Priscilla Reddy facilitated a session comprising of all participants to identify what the key concerns and barriers are, with respect to the national treatment program. Following a long discussion, participants identified a number of issues to be addressed in the small groups session afterwards. These included the following:

1. Human resources and capacity: brain drain, patient staff ratio; overburdened health care system and workers.

2. Monitoring and evaluation: lack of criteria; lack of transparency; problem of accountability.

3. Poor involvement of local committees, political councillors, and faith-based organizations.

4. Poor health-seeking behaviours among communities.

5. Neglected areas: involvement of traditional healers; the problem of mixed care; and lack of attention to the needs of elderly caregivers looking after dependents some of whom are living with HIV and AIDS.

6. The fragmentation of intersectoral collaboration is a key barrier. Government and NGO collaboration is not strong. The roles and responsibilities of different groups are not clear and the existing coordination mechanism is weak. 
7. Harnessing the potential of clinic committees is necessary. There are issues surrounding their selection, formation, roles, capacity, accountability, and support as well as their interaction with NGOs, CBOs and communities.

\section{Group sessions: Strategy development}

Participants were divided into small groups of 9-12 and asked to focus on a particular theme. Under the different themes they were requested to discuss what was working, what was not working, barriers and challenges, and solutions.

\section{Group 1: Theme-NGOs/FBOs/CBOs}

What is working:

- VCT programs outside of clinical settings delivered at the community level forms an important entry point to treatment.

- Effective referral to treatment.

- FBOs/NGOs using retired nurses who are skilled for VCT.

Barriers:

- Confusion between vaccines and ARVs.

- Men are not assessing treatment sufficiently; men not using condoms adequately

- Conflict between services and counselling provided by traditional healers and formal health providers.

- Choosing between traditional treatment and ART.

- Disagreement about ABCs for prevention.

- Families not prepared for treatment.

- Different funding affiliations and agendas tend to fractionalize community strategies and responses.

- FBOs are not accepting of men who have sex with men (MSM).

- Churches and their leaders not informed or involved.

- Referrals strategies (down and up referral) not clearly defined and implemented.

- Exploitation of people living with HIV by money lenders, family members, etc. because of the grant they get.

Solutions:

- An institutional body to manage coordination and collaboration is required.

- Sustainable income generation models for communities.

- Support for communities to be involve in ART services and program, which are driven by local priorities.

\section{Group 2: Theme-Government}

What is working:

The roles of government in treatment are diverse, and they are successful in a number including:

- Facilitating HBC.

- Good support through social grants.

- Defining criteria for eligibility to treatment. 


\section{Barriers:}

The issue of clinic committees recommended by government is of importance. However, these are not working well, and action needs to be taken to improve their performance and relevance. They have key roles in promoting community participation. Clinic committee members are influential and can mobilize communities readily, educate the community, facilitate interactions/exchange between facility and community teams; coordinating services, referring patients between home-based care, NGOs and CBOs.

However, clinic committees are not functioning effectively. People are not aware of their existence. There is a degree of confusion about their role. They are often set-up by clinic staff rather than the community, and there is always a power issue because they report to the people who established them. There is also unhealthy competition with other community committees. Clinic committee members are not as active as they ought to be either because of poor motivation, lack of interest, or competing demands.

\section{Solutions:}

The solutions recommended by this group include documenting experiences where clinic committees are effective, and involved in treatment services. It is necessary to clarify roles and build the capacity of committees. This should not be done by the government; rather NGOs contracted to facilitate this process.

\section{Group 3: Theme-Extended Family}

What is working:

- Sharing scare resources and applying them to those who need care.

- Child-headed households are increasing, and communities are making the effort to support such families.

- Informal carers are putting in a lot of effort into care; families are caring and taking on the burden of care, which would have passed to the health system.

- Traditional healer for example is providing more than just care. They also give spiritual and emotional support.

Due to historical factors, the extended family has been weakened. However with the grant system, more families are being given the support to cope with social grants. The factors responsible for this include a sense of responsibility by families showing a high level of commitment to care for their members. There is also a cultural aspect to this-traditionally families are expected to care for their relatives, especially when ill or in times of death. Families are willing to share resources.

\section{Barriers:}

- Disclosure of status by women. They are still prone to high levels of stigma and violence.

- Acceptance of HIV infection by individuals - people are still in denial and that leads to delay in accessing treatment.

- Information on treatment for all is lacking.

- The perception that free drugs may not be good could be affecting proper use.

\section{Solutions:}

- Quality of education needs to be improved. It is important that information is culturally sensitive, specifically tailored to youth, women, and other sub groups. 
- We need to ensure jobs and skills for people on ART who have recovered to contribute to their communities and families. This will put their lives back on track by giving them a sense of dignity.

- There is a lot of untapped community resources which should be better exploited; e.g. the use of community leaders, imbizos, political leaders, and church leaders and ministers who tend to be influential in rural areas.

\section{Group 4: Theme-Traditional Healers}

What is working:

- Traditional healers have more time with patients; they do not tend to stigmatize patients, and they are available 24 hours. Traditional healers have established trust with the community over a long period. They respond to their patients in a positive way, offer hope, are not judgmental, give one-on-one care that is comprehensive in nature, and have affordable services. In comparison, with health service providers, one needs to worry about confidentiality.

- Elements that make the work of traditional healers effective include:

- Training by health department; there is money and resources for training.

- They form part of the hospital team in some places and follow the national health policy; they refer; they belong to associations that can regulate what they do and are open to working with the formal health sector.

Barriers:

Poor coordination gives room for bogus traditional healers to operate. They also tend to work in isolation, and they feel threatened, not wanting to gain new ideas. Many of them are not educated, this creates a barrier in terms of how they can be trained. They also may claim to have a cure for AIDS, which misleads the community and patients.

Solutions:

- Ensure they belong to an association.

- Build trust among traditional healers.

- Keep their knowledge protected.

- Get them involved in research, especially to know about ethical issues.

- Acknowledge them for their contributions in research.

- Prepare policy brief on relevant research findings and recommendations through the department and policy makers.

General:

- There is concern about exploitation by traditional healers, especially those claiming to have a cure and exploiting HIV-positive people. Also, it is important to deconstruct the different types of traditional healers, and what contributions they can make to treatment. They are not a homogenous group.

\section{Group 5: Theme-Legislation}

What is working:

- The government is in a position to enact policies and laws and to enforce them. There are a number of guidelines already for treatment and other health and social services. 
What is not working:

- Inadequacy of targeted laws, policies and guidelines to support programs to perform effectively. There are numerous gaps and weaknesses in terms of legislation.

Barriers:

- Interface between government and community is confusing.

- Clinic committees - stakeholders, which are potentially a very powerful tool but the situation is very confusing. Their roles and responsibilities are unclear, and what caregivers should be doing and them.

- Caregivers need incentives and capacity building.

- Communication between clinic staff and the community not taking place.

- Community mobilization and education.

- Coordination and referral are weak.

Solutions:

- Document good practices.

- Ensure clarity of roles and responsibilities for clinic committee members.

- Define and develop necessary guidelines, polices and legislation.

- Build capacity to implement policies, guidelines, etc. 


\section{Appendix 1: Lists of Participants}

\begin{tabular}{|c|c|c|}
\hline Name & Organization/Affiliation & Address/Tel. No. \\
\hline Ledingah Resinah & Community & 405 Zone 3 \\
\hline Mankga Priscilla & Community & 455 Zone 3 \\
\hline Nkgapele Dorah & Community & 313 Zone 5 \\
\hline Semenya Jane & Ame HBBC & 807 Zone 5 \\
\hline Maswameng Thandi & Ame HBBC & 2262 Zone 2 \\
\hline Raphahlela Maria & Clinic Committe & 386 Zone 8 \\
\hline Maredi Violet & Community & 398 Zonen3 \\
\hline Mathaba Esther & Clinic Committee & 2838 Zone2 \\
\hline Deka Mahlodi & Clinic Committee & 34 Zone Ext \\
\hline Mokoena Minah & Community & 316 Zone 3 \\
\hline Mamoribolla Lumka & Community & \\
\hline Letsoalo Alletta & Community & 397Zone 3 \\
\hline Dlamini Martha & Traditional Healer & 530 Zone 3 \\
\hline Sebone Sarah & Community & 396 Zone 3 \\
\hline Mokubedi Freda & Community & 393 Zone 3 \\
\hline Matome Martina & Community & 04 Zone 3 \\
\hline Mashala Aileen & Community & 1079 Zone 3 \\
\hline Nkoana Rosa & Community & 403 Zone 3 \\
\hline Matlala Hilda & Community & 06Zone 3 \\
\hline Thema Dishrah & Clinic Committee & 56 Zone 2 \\
\hline Shadung Johana & Clinic Committee & 6 Zone 3 \\
\hline Seakame Johannah & Clinic Committee & 3205 Zone 2 \\
\hline Mogale Rosina & Clinic Committee & 3634 Zone 2 \\
\hline Seduma Ophrina & Clinic Committee & 1224 Zone 3 \\
\hline Mushi Germina & Community & 123 Zone 3 \\
\hline Lemeko Frans & Community & 1769 Zone 3 \\
\hline Msinga Rahab & Community & 97 Zone 3 \\
\hline Legodi Betty & Community & 3226 Zone 2 \\
\hline Mokgopo Elizabeth & Community & 322 Zone 3 \\
\hline Thobakgale Freddy & TAC & $\begin{array}{l}26 \text { Thabo Mbeki Street,Alsmith } \\
\text { Building Pietersburg }\end{array}$ \\
\hline Mavumo M.D. & Clinic Committee & 3419 Zone 2 \\
\hline Badimo R.N. & Clinic Committee & 122 Zone 3 \\
\hline Lediga Jostina & Community & 395Zone 3 \\
\hline Mokou Anna & Clinic Committee & 1706 Zone 4 \\
\hline Machaka Elizabeth & Zone 3 Clinic & Zone 3 Clinic \\
\hline Maria Malope & Zone 3 Clinic & 2075 Zone 4 \\
\hline
\end{tabular}

Participants' List, Community Dissemination Meeting at Pokoane Clinic February 2006 (Limpopo province)

\begin{tabular}{|l|l|l|}
\hline NAME & ORGANIZATION & ADRESS/Cellphone No. \\
\hline Leshalabe Makopi & Phokaene HBC & 0822180430 \\
\hline Phala Lephoula & Nehienekema HBC & 0732953215 \\
\hline Maswinyaneng Lucy & Mohlarekoma HBC & 0132640493 \\
\hline Ratau M.M. & Mohlareke & \\
\hline Anna & Musannana & \\
\hline Dorckas & Mafego & \\
\hline Ngele Nomthandazo & Pokoane HBC & 0823675172 \\
\hline Kgapane Kubjarra & Lesedi Counseling Centre & 0765182955 \\
\hline Moropyane Mary & Clinic Committee & 0723662376 \\
\hline Phaphedi Monamo & Traditional Healer & 0837303555 \\
\hline
\end{tabular}




\begin{tabular}{|l|l|l|}
\hline Tshehla M.E & The lord is My shepherd & 0761927954 \\
\hline Makola S.T & The lord is My shepherd & 0761927954 \\
\hline Jlaka M.G. & Lesedi C.C & 0721270575 \\
\hline Mathope Shirley & Lesedi C.C & 0832067423 \\
\hline Talana Shirley & Lesedi C.C. & 0721270575 \\
\hline Lekwana Florance & Lesedi C.C. & 0721270575 \\
\hline Mamogobo Delinah & Pokoane HBC & 0720822403 \\
\hline Ratau Globby & Mohlarekoma HBC & 0761279596 \\
\hline Chego Betty & Mohlarekoma HBC & 0722946954 \\
\hline Mohlala Blanfina & Makoshala & N/A \\
\hline Ndlovu Anna M. & Makoshala & N/A \\
\hline Nkosi Alice & Makoshala & N/A \\
\hline Matlala K. Baatseba & Makoshala & N/A \\
\hline Mokolo Sylvia & Mohlarekoma & 0827461257 \\
\hline Zweni Sibiya & HST & Durban \\
\hline Mamra Ntsike & HST & Durban \\
\hline Nomtandazo Mini & Population Council, Horizon & Johannesburg \\
\hline
\end{tabular}

Participants' List, Dissemination Workshop at Mzisa Primary School, KZN March 2006

\begin{tabular}{|l|l|}
\hline NAME & ORGANISATION/AFFILIATION \\
\hline Duduzile Myeza & Community Garden \\
\hline Thembalethu Mthembu & Church member \\
\hline Siyabonga Mthembu & Church member \\
\hline Nonhlanhla Gumede & Learner \\
\hline Fikile Buthelezi & Learner \\
\hline Zandile Mthembu & Learner \\
\hline Hlengiwe Mngoma & Community member \\
\hline Mabuyi Mthembu & Learner \\
\hline Zinhle Mthembu & Learner \\
\hline Thandekile Mthembu & Community member \\
\hline Simon Mthembu & Church leader \\
\hline Doreen Mjadu & Community garden \\
\hline Bongani Mvelase & Community member \\
\hline Lindani Myeza & Learner \\
\hline Sicelo Gumede & Learner \\
\hline D. Myeza & School committee member \\
\hline B. Mathonsi & School Committee member \\
\hline Nelisiwe Mkhize & Community garden \\
\hline Elsie Myeza & CHW/ community garden \\
\hline Khethiwe Mathonsi & Community member \\
\hline Samukelisiwe Mathonsi & Community member \\
\hline Thembani Myeza & Community member \\
\hline Nokuhkanya Mathonsi & Learner \\
\hline Philisiwe Msebeni & Learner \\
\hline Bonisiwe Mathonsi & Learner \\
\hline Zinhle Ntombela & Learner \\
\hline Ntombifuthi Ntonmbela & Learner \\
\hline Dumisile Ntuli & Learner \\
\hline Bheki Gumede & Community member \\
\hline Bonginkosi Mathonsi & Learner \\
\hline Nkululeko Mathonsi & Learner \\
\hline Dumi Mathonsi & Learner \\
\hline Seluleko Mkhize & Learner \\
\hline S. Mkhize & Community member \\
\hline J. Mhlongo & Community member \\
\hline R. Mpanza & Community garden \\
\hline & \\
\hline
\end{tabular}




\begin{tabular}{|l|l|}
\hline Njabulo Gumede & Learner \\
\hline B. Gumede & Community member \\
\hline Phumlani Mbonambi & Teacher \\
\hline Matozi Khuzwayo & Ward councilor \\
\hline J. Shandu & Community member \\
\hline Sbu Biyela & Community member \\
\hline Sbusiso Myeza & Learner \\
\hline Busani Myeza & Community member \\
\hline Nkosinathi Mathonsi & Community member \\
\hline Khulekani Gumede & Learner \\
\hline Sandile Gumede & Learner \\
\hline Ndumiso Gumede & Learner \\
\hline
\end{tabular}

Participants' List, Dissemination Workshop at Maphumulo Zagqayeni March 2006

\begin{tabular}{|l|l|}
\hline NArch 2006 & ORGANISATION/AFFILIATION \\
\hline Bheki Cele & Induna \\
\hline Saja Gcabashe & None \\
\hline Bantu Gcabashe & None \\
\hline Mshini Gcabashe & None \\
\hline Mhlo Mkhize & None \\
\hline Themba Cele & None \\
\hline Mr. Zuma & None \\
\hline Mwela Khumalo & None \\
\hline Sizakele Khumalo & None \\
\hline Phetheni Dube & None \\
\hline Funani Manqele & None \\
\hline Sizakele Dube & None \\
\hline Themnbeni Zulu & None \\
\hline Bhentshi Hlongwane & None \\
\hline Grater Gumede & None \\
\hline Mthunzi Mbambo & None \\
\hline Philisiwe Nxumalo & None \\
\hline Mabilili Khumalo & None \\
\hline Mlisa Khumalo & None \\
\hline Sipho Mkhize & None \\
\hline Sthembile Cele & None \\
\hline Travina Gumede & None \\
\hline Nomcabango Mdlalose & None \\
\hline Thabani Nxumalo & None \\
\hline Ntombi Zulu & None \\
\hline Goodness Dube & None \\
\hline Bongiwe Dlamini & None \\
\hline Mzomuhle Dube & None \\
\hline Mchazeni Mthiyane & None \\
\hline Hilda Ndlovu & None \\
\hline Jabu Gcabashe & None \\
\hline Bathembile Mthembu & None \\
\hline Thandi Mbele & None \\
\hline Phumzile Gcabashe & None \\
\hline Jabu Shezi & None \\
\hline Sbu Mthiyane & None \\
\hline Robert Dube & None \\
\hline Vivian Mngadi & None \\
\hline Khumbulile Mbambo & None \\
\hline Pinky Mbambo & None \\
\hline Voctoria Mdletshe & None \\
\hline & \\
\hline
\end{tabular}




\begin{tabular}{|l|l|}
\hline Zibuyile Ngcobo & None \\
\hline Neli Ngiba & None \\
\hline Ntombi Nxumalo & None \\
\hline Denis Ngubane & None \\
\hline Lindiwe Mdlalose & None \\
\hline Gastina Mngoma & None \\
\hline Qondeni Mthiyane & None \\
\hline Hlengiwe Nxumalo & None \\
\hline Florence Blose & None \\
\hline Sholiphi Mbambo & None \\
\hline Nomusa Mngoma & None \\
\hline Jabu Mabanga & None \\
\hline Mathombi Nala & None \\
\hline Mhlangano Zungu & None \\
\hline
\end{tabular}

Participants' List, Dissemination Workshop at Maphumulo Mbitane
March 2006
\begin{tabular}{|l|l|}
\hline NAME & ORGANISATION \\
\hline S.G. Ncamu & CPF \\
\hline Zomusa Khanyile & CHW \\
\hline Thoko Luthuli & CHW \\
\hline Teresa Xaba & CHW \\
\hline Bongiwe Sithole & CHW \\
\hline Ntombenhle Ngcobo & CHW \\
\hline Sesi Khumalo & CHW \\
\hline Ntombikayise Ngcobo & CHW \\
\hline Zodwa Goqo & CHW \\
\hline Dudu Chamane & CHW \\
\hline Nkosingiphile & HBC Volunteer \\
\hline Phoselakhe Nxumalo & HBC volunteer \\
\hline Zandile Zondi & None \\
\hline Thandazile Mhlongo & None \\
\hline
\end{tabular}

Participants' List, National Strategy Meeting at J ohannesburg (Balalaika) June 2006

\begin{tabular}{|l|l|l|l|}
\hline Organisation & Name & E-mail address & Telephone \\
\hline Africare & $\begin{array}{l}\text { Nomawethu } \\
\text { Mfenyana }\end{array}$ & nomawethu@africare.co.za & 0726068201 \\
\hline $\begin{array}{l}\text { AIDS } \\
\text { CONSORTIUM }\end{array}$ & Denise Hunt & denise@aidsconsortium.org.za & 0114030265 \\
\hline ARK SA & Anita Jason & anita@arkonline.org & 0214470822 \\
\hline $\begin{array}{l}\text { Atlantic } \\
\text { Philanthropies }\end{array}$ & Zola Madikizela & z.madikizela@atlanticphilanthropies.org & 0118800995 \\
\hline CARE & Venon Baloyi & venon@care.co.za & 0117280218 \\
\hline CHP & Bulelwa Ngoma & & 0114899881 \\
\hline $\begin{array}{l}\text { Community AIDS } \\
\text { Response }\end{array}$ & Morelle Masike & admin@care.co.za & 0117280218 \\
\hline DOH - Gauteng & Dr. Francis Akpan & francis.akpan@gauteng.gov.za & 0113553394 \\
\hline DOH - KZN & Thilo Govender & thiloshini.govender@kznhealth.gov.za & 0333953003 \\
\hline HIVSA & Stubbs Maluleke & maluleka@hivsa.com & 0119899782 \\
\hline HIVSA & Helen Struthers & struthersh@hivsa.com & 0119899700 \\
\hline HIVSA - USAID & Karen James & kjames@hivsa.com & 0119899739 \\
\hline Hope Worldwide & Sophy Phalatse & & 0114436609 \\
\hline Hope Worldwide & Nomsa Walaza & & 0119844422 \\
\hline
\end{tabular}




\begin{tabular}{|c|c|c|c|}
\hline Hospice SA & Sibongile Mafata & 0ffices@hospicewitwatersrand.org.za & 0119825835 \\
\hline $\begin{array}{l}\text { Hospice } \\
\text { Witwatersrand }\end{array}$ & Barbara Campbell & barbara@hospicewits.co.za & 0114839100 \\
\hline HST & Ashnie Padarath & ashnie@hst.org.za & 0313072954 \\
\hline HST & Zweni Sibiya & & 0313072954 \\
\hline $\begin{array}{l}\text { ICAP - Columbia } \\
\text { University }\end{array}$ & Natalie Kaunda & nkaunda@siza.co.za & 0839836262 \\
\hline JEAPP & Maria Kurian & maria@jeapp.org.za & 0124272305 \\
\hline MCDI & Farshid Meidany & fmeidany@gmail.com & 0834537386 \\
\hline MRC & Priscilla Reddy & priscilla.reddy@mrc.ac.za & 0219380453 \\
\hline $\begin{array}{l}\text { NAPWA- National } \\
\text { Office }\end{array}$ & Nkululeko Nxesi & nkululeko.nxesi@napwa & 0112556414 \\
\hline $\begin{array}{l}\text { National Dep. of } \\
\text { Social } \\
\text { Development }\end{array}$ & $\begin{array}{l}\text { Abram } \\
\text { Phahlamohlaka }\end{array}$ & abramp@socdev.gov.za & 0123127832 \\
\hline Ndlovu Clinic & Lindie Botha & lindie@ndlovumc.org & 0823044341 \\
\hline $\begin{array}{l}\text { NDOH - Belgian } \\
\text { Technical } \\
\text { Cooperation }\end{array}$ & Vincent Tihon & vincent.tihon@btcctb.org & 0123120076 \\
\hline $\begin{array}{l}\text { Perinatal HIV } \\
\text { Research Unit }\end{array}$ & Susan Kekana & kekana@hivsa.com & 0119899939 \\
\hline Population Council & Thandi Mini & nmini@pcjoburg.org.za & 0114384400 \\
\hline Population Council & Eka Williams & ewilliams@pcjoburg.org.za & 0114384400 \\
\hline Population Council & Lewis Ndlhlovu & lndhlovu@pcjoburg.org.za & 0114384400 \\
\hline Population Council & Nathi Sohaba & nsohaba@pcjoburg.org.za & 0114384400 \\
\hline Population Council & Ayo Ajayi & aajayi@popcouncil.org & 233244691472 \\
\hline Population Council & Naomi Rutenberg & & \\
\hline PSASA & Corrie Oosthuizen & coosthuizen@gmx.net & 0176471525 \\
\hline PWN & Prudence Mabele & pmabele@pwn.org.za & 0845710721 \\
\hline RHRU & Merci Tellie & mtellie@rhrujhb.co.za & 827761213 \\
\hline RHRU & Ngobeni Steve & ngobeni@hivsa.com & 0119899752 \\
\hline RHRU & Busisiwe Dlamini & b.dlamini@rhru.co.za & 0117257700 \\
\hline Right to care & Busi Makhanya & busi.makhanya@righttocare.org & 0112768860 \\
\hline Right to care & Dr. Thembisile Xulu & thembi.xulu@righttocare & 0112768871 \\
\hline Right to care & Appiah Kuku & kuku.appiah@righttocare.org & 0826593626 \\
\hline SACBC & Dr. Maponyane & mmaponyane@sacbc.org.za & 0123236458 \\
\hline $\begin{array}{l}\text { Soweto Ministries } \\
\text { Fraternal }\end{array}$ & Brian Mfrana & & 0832106901 \\
\hline TAC & Gorrdon Mthembu & gordon@tac.org.za & 0728977552 \\
\hline TAC - KZN & Richard Shandu & & 0313043673 \\
\hline TAC - Limpopo & Lester Baloyi & & 0155563341 \\
\hline TAC - Limpopo & Lawrence Mbalati & lawrence@tac.org.za & 0733159728 \\
\hline TAC - Limpopo & $\begin{array}{l}\text { Phoklogolo } \\
\text { Ramothwala }\end{array}$ & phologolo@tac.org.za & 0155563341 \\
\hline USAID & Annie Latour & alatour@usaid.gov & 0124522236 \\
\hline $\begin{array}{l}\text { Wits Palliative } \\
\text { Care }\end{array}$ & Dr. Lesley Bamford & lesleyb@witspalliative.co.za & $\begin{array}{l}0114898567 / \\
0827731860 \\
\end{array}$ \\
\hline $\begin{array}{l}\text { Wits Palliative } \\
\text { Care } \\
\end{array}$ & Natalya Dinat & ndinat@sentechsa.com & 0119334031 \\
\hline WitsUniversity & Lesley Scott & lesley.scott@nhls.ac.za & \\
\hline
\end{tabular}


Participants' List, Provincial Dissemination Meeting at Durban, KZN

August 2006

\begin{tabular}{|c|c|c|c|}
\hline Organisation & Name & E-mail address & Telephone \\
\hline Aids Foundation & Mandla Nyuswa & Nozuko@aids.org.za & 0312772701 \\
\hline DOSD-KZN & Zama. G. Gumede & dalikaa@uld.kzntl.gov.za & 0823283719 \\
\hline DOSD-KZN & M.S. Dlwati & hlubid@vodamail.co.za & 0333954911 \\
\hline DOSD-KZN & H.J.B. Dubazana & khanyilz@bbp.kzntl.gov.za & 0313368815 \\
\hline Gender Aids Forum & Ntokozo Madlala & ntokozo@gaf.org.za & 0313041253 \\
\hline HEARD & Suraya Dawad & dawads1@ukzn.ac.za & 0312601476 \\
\hline Hlongwa CBO & Patrick Ntuli & patrickvntuli@yahoo.com & 0835838609 \\
\hline HopeWorld Wide & Menye Zingisa & benntsikanye@yahoo.com & $\begin{array}{l}031 \text { 2619111/ } \\
0846680302\end{array}$ \\
\hline HopeWorld Wide & Ben Ntsikanye & benntsikanye@yahoo.com & $\begin{array}{l}0312619111 / \\
0846680302\end{array}$ \\
\hline HST & Petrida Ijumbu & petrida@hst.org.za & 031304015 \\
\hline HST & Ashnie Padarath & ashnie@hst.org.za & 0834681251 \\
\hline HST & Zweni Sibiya & zweni@hst.org.za & 0313072954 \\
\hline KZN CBO Coalition & Themba Blose & thembaj@welcome.co.za & $\begin{array}{l}031 \text { 3017188/ } \\
0768297431\end{array}$ \\
\hline $\begin{array}{l}\text { KZN DOH District } \\
\text { Managers }\end{array}$ & Mrs F Ngema (acting) & ngemaf@dohho.kzntl.gov.za & \begin{tabular}{|l|}
$034) 2999100 /$ \\
0844661023
\end{tabular} \\
\hline $\begin{array}{l}\text { KZN DOH District } \\
\text { Managers }\end{array}$ & Sonto Radebe & & 0343123123 \\
\hline $\begin{array}{l}\text { KZN DOH District } \\
\text { Managers }\end{array}$ & Mrs N.P. Khwela & h041239@dohho.kzntl.gov.za & (039) 834300 \\
\hline $\begin{array}{l}\text { KZN DOH District } \\
\text { Managers }\end{array}$ & Mrs L Brysiewicz & brysiewiczl@dohho.kzntl.gov.za & 036) 6312202 \\
\hline $\begin{array}{l}\text { KZN DOH District } \\
\text { Managers }\end{array}$ & Miss Maphalala & & 0366312202 \\
\hline $\begin{array}{l}\text { KZN DOH District } \\
\text { Managers }\end{array}$ & Khumalo Aubrey & h031836@dohho.kzntl.gov.za & 0820812767 \\
\hline $\begin{array}{l}\text { KZN DOH District } \\
\text { Managers }\end{array}$ & Mkhize Ntokozo & ntokozo.mkhize@kznhealth.gov.za & 0324373500 \\
\hline $\begin{array}{l}\text { KZN DOH } \\
\text { PMTCT/VCT }\end{array}$ & Bongi Ngubane & bongi.ngubane@kznhealth.gov.za & 0342999100 \\
\hline $\begin{array}{l}\text { KZN DOW District } \\
\text { Managers }\end{array}$ & Themba Msikinya & & 0358743798 \\
\hline Life Line & Vuyi Mbele & IInatal@hit.co.za & 0313031344 \\
\hline M2M Programme & Jon Barry & jon@m2m.org & 0791827702 \\
\hline M2M Programme & Micheal & michael@m2m.org & 0824991313 \\
\hline $\begin{array}{l}\text { Maphumulo Aids } \\
\text { Council }\end{array}$ & Chris Mhlongo & & 0324812047 \\
\hline $\begin{array}{l}\text { Maphumulo Life } \\
\text { Centre }\end{array}$ & Bongiwe Shange & bongeka001@webmail.co.za & 0826781909 \\
\hline MAYA & Sthandwa Ndlovu & & 0737690512 \\
\hline MCDI & Farshid Meidany & fmeidany@gmail.com & 0834537386 \\
\hline MRC & Thiroshini Govender & thgovender@mrc.ac.za & 0312423600 \\
\hline MRC & Thabo Cele & tcele@mrc.ac.za & 0783919588 \\
\hline MRC & Shegs James & & 0219380453 \\
\hline MRC & Thesla Palanee & tpalanee@mrc.ac.za & 0312423600 \\
\hline MRC & Tusani Kunene & tkunene@mrc.ac.za & 0312423600 \\
\hline MRC & TM.Tambo & tmtambo@mrc.ac.za & 0312423600 \\
\hline $\begin{array}{l}\text { Muthande Society } \\
\text { For the Aged }\end{array}$ & Thoko Molefe & msfta@saol.com & $\begin{array}{l}031332 \\
6853 / 6516\end{array}$ \\
\hline
\end{tabular}




\begin{tabular}{|l|l|l|l|}
\hline NAPWA & Mazwi Mngandi & napwakzn@sn.apc.org & $\begin{array}{l}0837102840 / 031 \\
3003914\end{array}$ \\
\hline NAPWA & Pat Hlongwane & napwakzn@sn.apc.org & $\begin{array}{l}0837102840 / 031 \\
3003914\end{array}$ \\
\hline NAPWA & Jabulani Hlatshwayo & napwakzn@sn.apc.org & $\begin{array}{l}0837102840 / 031 \\
3003914\end{array}$ \\
\hline Sinosizo & Moira Cocki & sinosizohbc@iafrica.com & 0319035722 \\
\hline TAC & Lihle Dlamini & lihle@tac.org.za & 0313043673 \\
\hline $\begin{array}{l}\text { Kniversity Of } \\
\text { Kwazulu Natal }\end{array}$ & Sibongile Maimane & maimanes@ukzn.ac.za & 0312602279 \\
\hline $\begin{array}{l}\text { University Of } \\
\text { KwazuluNatal }\end{array}$ & Yugi Nair & nairy3@ukzn.ac.za & 0312602279 \\
\hline Population Council & Ayo Ajayi & Aajayi@popcouncil.org & 233244691472 \\
\hline Population Council & Eka Williams & ewilliams@pcjoburg.org.za & 0114384400 \\
\hline Population Council & Nathi Sohaba & nsohaba@pcjoburg.org.za & 0114384400 \\
\hline Population Council & Nomtandazo Mini & nmini@pcjoburg.org.za & 0114384400 \\
\hline $\begin{array}{l}\text { University of } \\
\text { KZN/w.HH.R.U. }\end{array}$ & Mabu Sokhulu & sokhulu@ukzn.ac.za & $0312604685 /$ \\
\hline
\end{tabular}

Participants' List, Dissemination Meeting at Polokwane, Limpopo Province August 2006

\begin{tabular}{|c|c|c|c|}
\hline Organisation & Names & E-mail address & Telephone \\
\hline $\begin{array}{l}\text { Aganang CBO } \\
\text { Forums }\end{array}$ & D. Mamabolo & N/A & 0848814462 \\
\hline $\begin{array}{l}\text { Aganang CBO } \\
\text { Forums } \\
\end{array}$ & Monyebodi Maggie & N/A & 0768121012 \\
\hline $\begin{array}{l}\text { Aganang CBO } \\
\text { Forums }\end{array}$ & Mochitelo Salome & N/A & 0739931462 \\
\hline $\begin{array}{l}\text { Aganang CBO } \\
\text { Forums } \\
\end{array}$ & Chokoe Nancy & N/A & 0825922066 \\
\hline $\begin{array}{l}\text { Arise and Shine } \\
\text { Drop-in-Center }\end{array}$ & Mmabatho Kgashane & N/A & 0732060576 \\
\hline $\begin{array}{l}\text { Capricorn District } \\
\text { Municipality }\end{array}$ & Marxmann Joanna & joanna@cdm.org.za & $\begin{array}{ll}0824573663 \text { or } \\
0152941005\end{array}$ \\
\hline $\begin{array}{l}\text { Center for Positive } \\
\text { Care }\end{array}$ & Tshivhase Betty & posicare@mweb.co.za & 0159632012 \\
\hline CHOICE - Trust & Roper Kate & fiona.choice@mweb.co.za & 0153076329 \\
\hline Clinic 3 DOTS & Mokou Anna & N/A & 0731783360 \\
\hline $\begin{array}{l}\text { Clinic Committee } \\
\text { Zone } 3\end{array}$ & Badimo R.N. & N/A & 0828617733 \\
\hline $\begin{array}{l}\text { Clinic Committee } \\
\text { Zone } 3\end{array}$ & Machaka Elizabeth & N/A & 0833298420 \\
\hline DoH Limpopo & Pinini Zuki & pininiz@dhw.norprov.gov.za & 0152909000 \\
\hline Gundo Community & Nematei M.J. & gundodevelpment@telkom.net & 0832738681 \\
\hline HIV/AIDS Center & Galane Sara & & 0152902364 \\
\hline $\begin{array}{l}\text { HIV/AIDS } \\
\text { Prevention Group }\end{array}$ & Manhaeve Cecile & thusanan@esnet.co.za & 0147377650 \\
\hline HST & Padarath Ashnie & ashnie@hst.org.za & 0313072954 \\
\hline $\begin{array}{l}\text { Lepelle-Nkumpi } \\
\text { CBO Forum }\end{array}$ & Letsoalo Lydia & N/A & 0769379921 \\
\hline $\begin{array}{l}\text { Limpopo CBO } \\
\text { Network }\end{array}$ & Makgareetsa Morgan & & 0724372897 \\
\hline
\end{tabular}




\begin{tabular}{|c|c|c|c|}
\hline $\begin{array}{l}\text { Mapate HIV } \\
\text { Network }\end{array}$ & Nengwenani Docheth & mapatehiv@telkomsa.net & 0837717492 \\
\hline MIPPA & Salane Ndabane & N/A & 0820450784 \\
\hline MIPPA & Ramogale Elvis & N/A & 0847696923 \\
\hline $\begin{array}{l}\text { Molemole CBO } \\
\text { Forum/ Religious } \\
\text { HIV/AIDS }\end{array}$ & Morundi Martina & N/A & 0729549888 \\
\hline NAPWA & Sengwane Lawrence & napwalimpopo@mweb.co.za & 0152956017 \\
\hline NAPWA & Mahlo Poppy & napwalimpopo@mweb.co.za & 0152956017 \\
\hline Parent & Tsweleng Thomas & N/A & 0152236895 \\
\hline PASPWA & Semenya Moeder & & 0152232642 \\
\hline PASWA & Maselenyane Portia & N/A & 0152232642 \\
\hline PASWA & Masote Daniel & N/A & 0152232642 \\
\hline $\begin{array}{l}\text { Pholang Medical } \\
\text { Center - Mokopane } \\
\text { Private Roll-out }\end{array}$ & Malinda Mbulaheni & putswana@mweb.co.za & 0154918567 \\
\hline $\begin{array}{l}\text { Pholang Medical } \\
\text { Center - Mokopane } \\
\text { Private Roll-out }\end{array}$ & Modisakeg Christopher & N/A & 0720935456 \\
\hline $\begin{array}{l}\text { Polokwane } \\
\text { HIV/AIDS CBO } \\
\text { Forum } \\
\end{array}$ & Masoga Tlou & amozm@1-web.co.za & 0822127571 \\
\hline $\begin{array}{l}\text { Polokwane } \\
\text { HIV/AIDS CBO } \\
\text { Forum }\end{array}$ & Mokono M.A & N/A & 0823916318 \\
\hline $\begin{array}{l}\text { Polokwane } \\
\text { Municipality }\end{array}$ & Mhango Glen & & 0152902365 \\
\hline Population Council & Williams Eka & ewilliams@pcjoburg.org,za & 011438440 \\
\hline Population Council & Sohaba Nathi & nsohaba@pcjoburg.org.za & 0114384400 \\
\hline RADAR & Muvhango Lufuno & Lufunom@agincourt.co.za & 0137955076 \\
\hline RADAR & Ntlemo Ennica & Lufunom@agincourt.co.za & 0137955056 \\
\hline SANABP & Mashabela Makamele & N/A & 0152233712 \\
\hline SANABP & Malati Israel & & 0152233712 \\
\hline TAC & Fazi Oupa & oupa@tac.org.za & 0152915448 \\
\hline TAC & Mbalati Lawrence & lawrence@tac.org.za & 0152915448 \\
\hline TAC & Malapa Adam & & 0827925608 \\
\hline TAC & Tefu Violet & & 0765090929 \\
\hline TAC & Mosago Diana & & 0727038386 \\
\hline Takalani Nana & Sethosa Rachel & takalaninana@polokwane.com & 0825743949 \\
\hline Traditional healer & Monamo Phaphedi & N/A & 0837303555 \\
\hline Traditional healer & Mrs Letsoalo & & \\
\hline Turfloop - Limpopo & $\begin{array}{l}\text { Kgosimore Cynthia } \\
\text { Kgosi }\end{array}$ & cynthiak@ul.ac.za & $\begin{array}{ll}0152682431 / \\
082 & 2005209 \\
\end{array}$ \\
\hline \multirow{2}{*}{$\begin{array}{l}\text { UNIVEN Health } \\
\text { Unit }\end{array}$} & Mudzusi Helen & mudzusi@univen.ac.za & 0159628037 \\
\hline & Motloutsi Samuel & N/A & 0768325098 \\
\hline
\end{tabular}




\section{Appendix 2: Participants' Feedback Report}

\section{Participants’ Feedback Report: Provincial Dissemination meetings}

At the end of each meeting, participants filled-in evaluation questionnaires, which were aimed at collecting information on how the participants felt about the meetings. The results of participants' responses are summarized below.

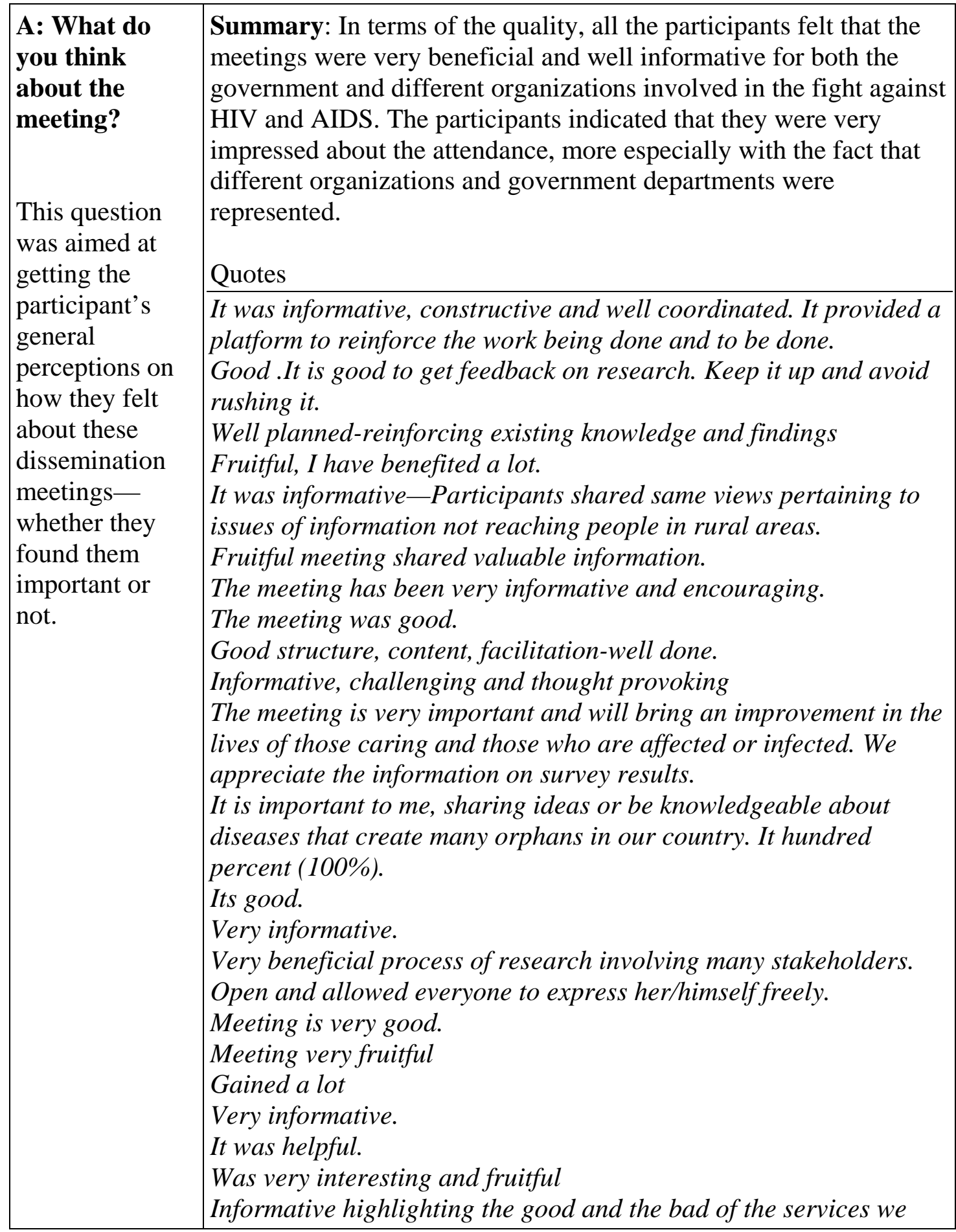




\begin{tabular}{|c|c|}
\hline & $\begin{array}{l}\text { are giving to communities } \\
\text { Meeting was very important allowed us to speak freely about our } \\
\text { communities. } \\
\text { Great very useful study. } \\
\text { Appreciated learnt a lot about PLHIV. } \\
\text { Interesting. } \\
\text { Good intent research results, relevant to providing the solution to } \\
\text { some challenges. } \\
\text { Wonderful, more impressive. } \\
\text { Very necessary and informative } \\
\text { Very informative, and people knew what they were speaking about } \\
\text { Very important as our PLWH do not access treatment } \\
\text { Very productive, brought a lot of community experiences, it also } \\
\text { gave a broader perspective and awareness of services in the } \\
\text { Province. } \\
\text { Meeting served as a platform for all role players and to reposition } \\
\text { the focus on developing the role players and increase the action on } \\
\text { treatment } \\
\text { Very informative and interesting } \\
\text { Interesting } \\
\text { It was a total challenge that gave a lot of information. } \\
\text { Meeting was very informative regarding the problems encountered } \\
\text { by people. } \\
\text { Very important information that will help me share it with others } \\
\text { The meeting is very much exciting. } \\
\text { Very informative and most useful, it shows that we are doing } \\
\text { something in our communities }\end{array}$ \\
\hline $\begin{array}{l}\text { B. Did this } \\
\text { meeting meet } \\
\text { your } \\
\text { expectations? }\end{array}$ & $\begin{array}{l}\text { Summary: Everyone felt that their expectations were met and } \\
\text { further highlighted that the research findings presented would be a } \\
\text { very useful resource, not only for the government, but also for their } \\
\text { communities. }\end{array}$ \\
\hline
\end{tabular}




\begin{tabular}{|c|c|}
\hline $\begin{array}{l}\text { C. Other } \\
\text { comments }\end{array}$ & $\begin{array}{l}\text { Needed more time to discuss research results. } \\
\text { Thanks for the opportunity } \\
\text { Involve youth and politicians. Advise nurses not disclose patient's } \\
\text { status. Also implement the dissemination results. } \\
\text { There should be district research station, which will collect all the } \\
\text { information not covered. } \\
\text { Thank you PC for a well-done job. } \\
\text { We have many patients who need urgent assistance in terms of } \\
\text { poverty alleviation. } \\
\text { Thanks for the research, we rurals are enriched we will be on our } \\
\text { feet to get the work done. } \\
\text { Hope whatever we discussed does not end in this boardroom, } \\
\text { Another thing is we never involve taxi drivers and truck drivers they } \\
\text { need to be sensitized Good structure, content, facilitation-well done. } \\
\text { Invite doctors and counselors for the next dissemination meeting. } \\
\text { Your presentation will make a difference in our lives. } \\
\text { Needed more time to discuss. Keep it up and please implement } \\
\text { those issues we have discussed. } \\
\text { Keep up the good thing that you are doing Halala! } \\
\text { Thank you for the feedback } \\
\text { Thank you for seeking our input. Will invite head of our } \\
\text { organization-Traditional Healers. } \\
\text { Community involvement important in treatment support } \\
\text { Intervention strategies shared/identified will be good to implement, } \\
\text { the sooner the second phase of the study. } \\
\text { Bring care providers as well } \\
\text { Thanks for involving us. Next time do this research in a bigger } \\
\text { scale. } \\
\text { Thank you bring positive research for the second phase. } \\
\text { Keep up the good work, so that we improve access to antiretroviral } \\
\text { amongst communities. } \\
\text { Appreciated your presentation and feedback. } \\
\text { Involve general practitioners in the future stud. } \\
\text { Please help our people in rural areas to come and access treatment } \\
\text { in clinic. } \\
\text { Involve all stakeholders } \\
\text { Thank you so much for carrying out this research, because it } \\
\text { uprooted a lot of important issues about ART. } \\
\text { I appreciate being part of the research. } \\
\text { Thanks for the invite it was very informative } \\
\text { Time was limited, thank you for conducting this research and for } \\
\text { inviting us. } \\
\text { Thank you for such wonderful sharing of results. }\end{array}$ \\
\hline
\end{tabular}




\section{Appendix 3: Presentations}

Understanding Challenges to Community Participation in HIV and AIDS Services

Ashnie Padarath and Zweni Sibiya

Highlights of Issues \& Recommendations: Strategy Development Meeting, Joburg

Eka Esu Williams

Dept of Health: KZN

M.S. Dlwati

Community Participation-Who? Why? How?

Thilo Govender

Exploring Ways of Supporting the Comprehensive HIV and AIDS Care,

Management and Treatment Plan- "Building a Caring Society Together"

A. Phahlamohlaka

National Strategy Dissemination Meeting, Johannesburg

43

N. Dinat 


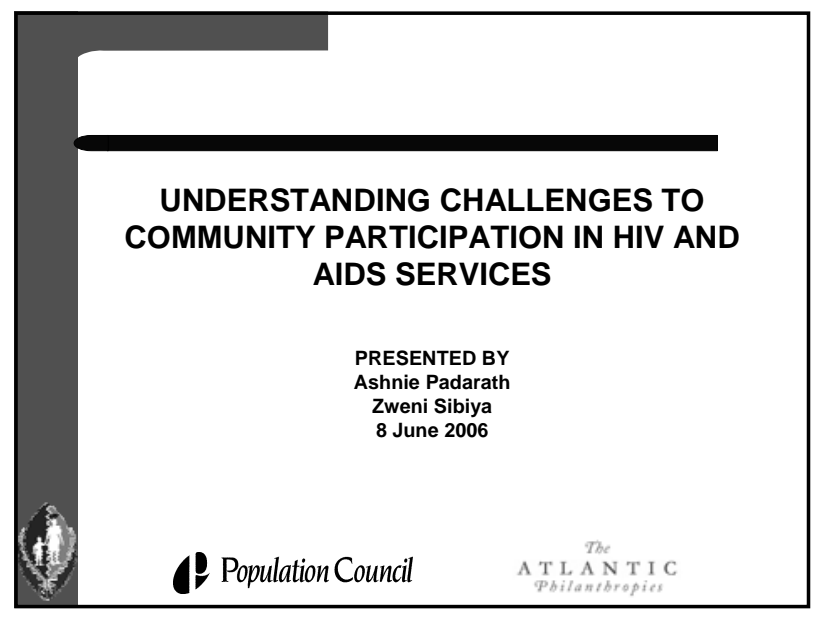

\section{Acknowledgements}

We appreciate the contributions of:

- The research team:

Population Council: Cathy Searle and Eka Williams

HST: Mamra Ntsike and Antionette Ntuli

- Partners:

DoH-KZN

DoHSW-Limpopo

- Research participants in KZN and Limpopo

$$
\text { O Population Council A T L A N T I C }
$$

\section{Methodology}

- Focus Group Discussions and interviews: 284 people

- Breakdown: total of 71 FGDs and interviews. 42 in KZN; 29 in Limpopo

- Health care workers, community workers, PLHA, traditional healers, community leaders, NGOs/CBOs clinic committees, and ordinary community members

(P. Population Council

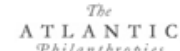

Objectives
- To understand the obstacles facing
communities in accessing and using treatment
related services
- To assess the role that community-based
organizations (CBOs) can play in the ART
rollout.
- To gather information on how communities are
addressing the challenges they face
$\quad \mathbf{P}$ Population Council
4y

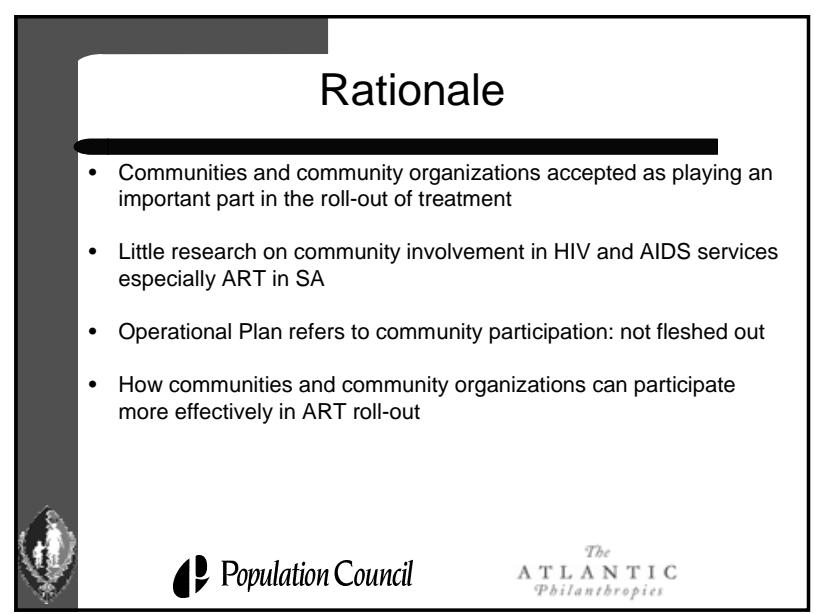

\begin{tabular}{|l|} 
Sites \\
- Four sites: two in KZN and two in Limpopo - one urban \\
and one rural in each province. \\
- Chesterville - urban KZN \\
- Maphumulo - rural KZN \\
- Polokwane - urban Limpopo \\
- Sekhukhune - rural Limpopo \\
- Research was conducted July-December, 2005 \\
(P Population Council
\end{tabular}




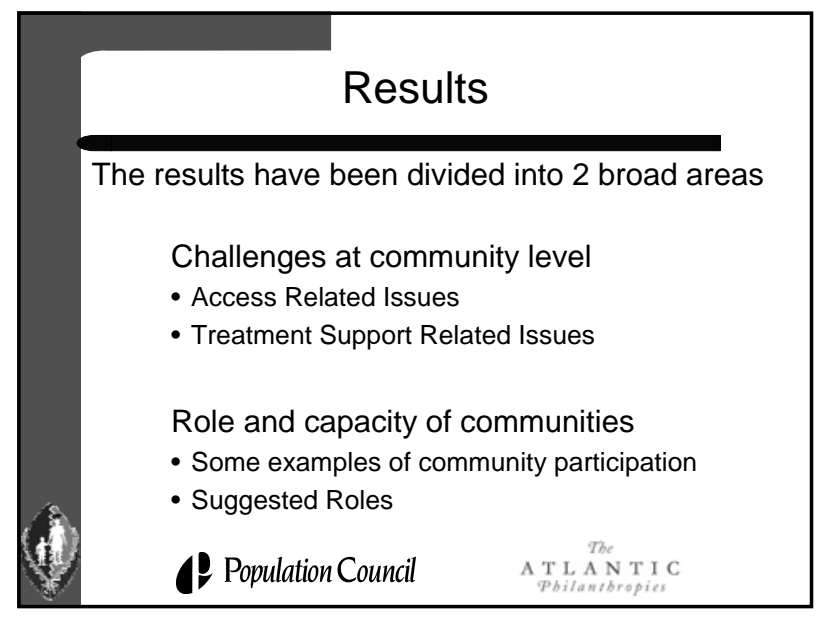

\section{Access Related Issues}

- Perceptions on HIV and AIDS

- Perceptions on ARVs

- Stigma

- Health Seeking Behaviour

- Socio-economic Factors

- Family and Community Attitudes

(1) Population Council A T L The A T I C

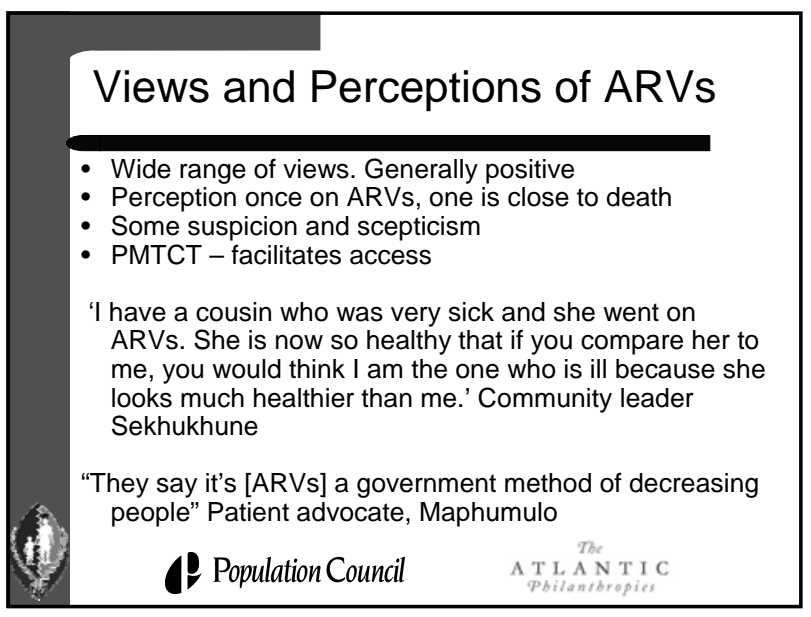

\section{Community Perceptions of HIV and AIDS}

- HIVIAIDS perceived as a serious problem "We are burying young people every weekend. There are many orphans here. AIDS is finishing people.' Traditional Healer, Chesterville.

- Lack of openness about the issue

'There is someone that I know who has lost a lot of weight but he does not say that he is HIV positive. But it's apparent that he might be HIV positive.' Male, Polokwane

- Response: inadequate for youth and women

(1) Population Council

\section{Quotes: ARVs}

Most of them believe that ARVs are killing people. They think once you start ARVs you will die very soon' Youth Group member, Chesterville

'I have seen people walk after being severely weak. I have seen their health improve when they are on ARVs. They improve the lives of people and therefore they are able to live longer.' Community leader Maphumulo

(P Population Council

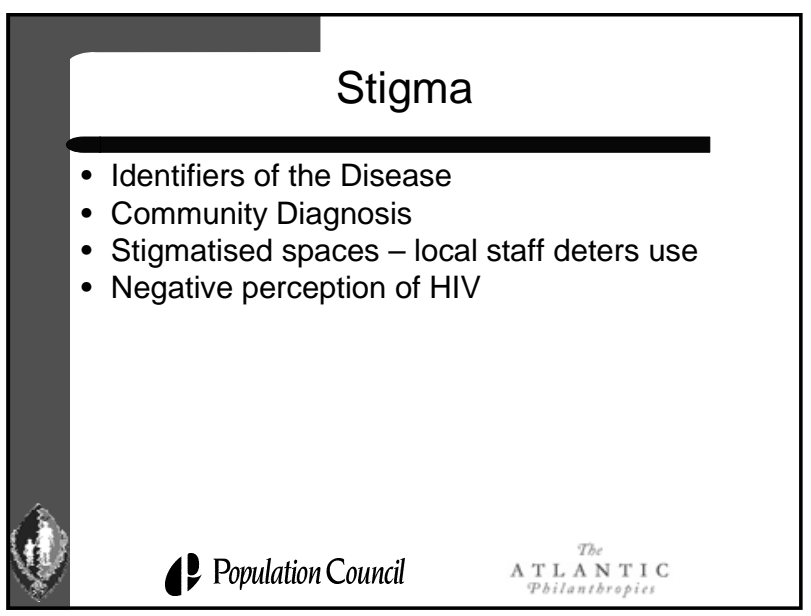




\section{Quotes: Stigma}

- 'Its because its perceived as a sexually transmitted disease. Therefore when we talk about HIV positive people, we always refer to this as a disease of someone who flirts'. Clinic sister, Sekhukhune

- 'We are afraid of people with HIV and AIDS we even gossip and laugh at them.' FDG with women, Polokwane

- 'In the community people keep the information to themselves, sometimes they do not even want to tel their families because they believe they might be told to cook and eat alone'. PLHA, Maphumulo

F Population Council A T L A N T I C

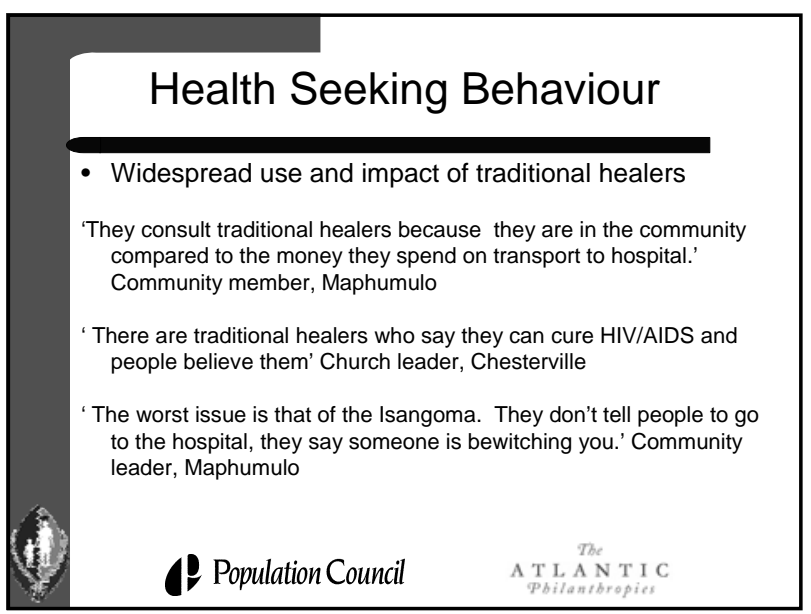

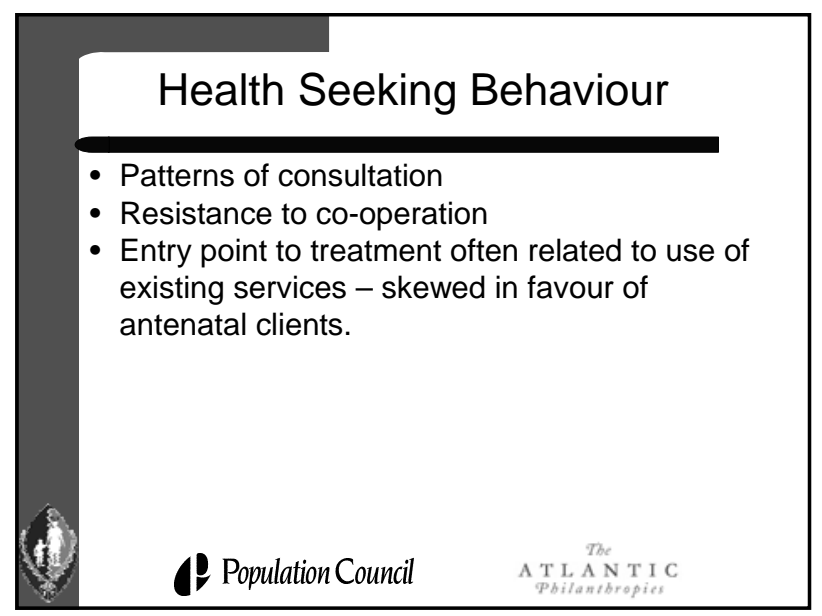

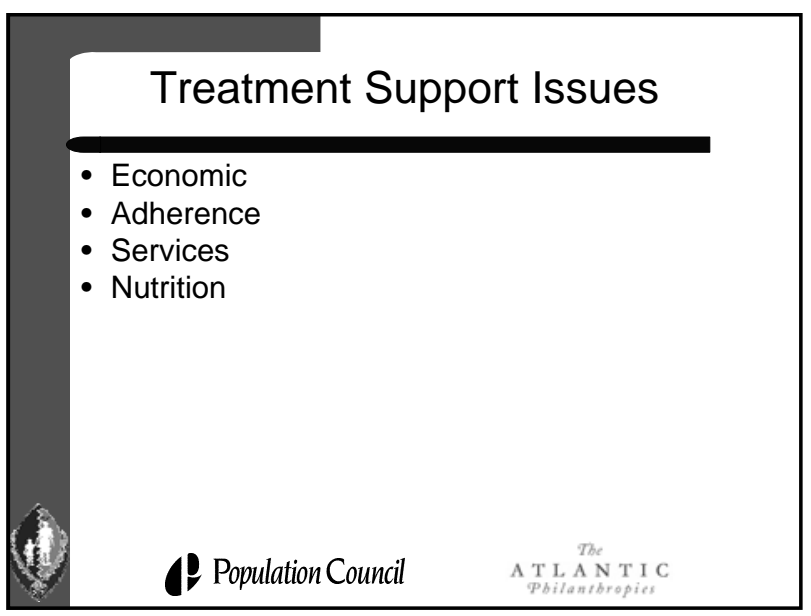



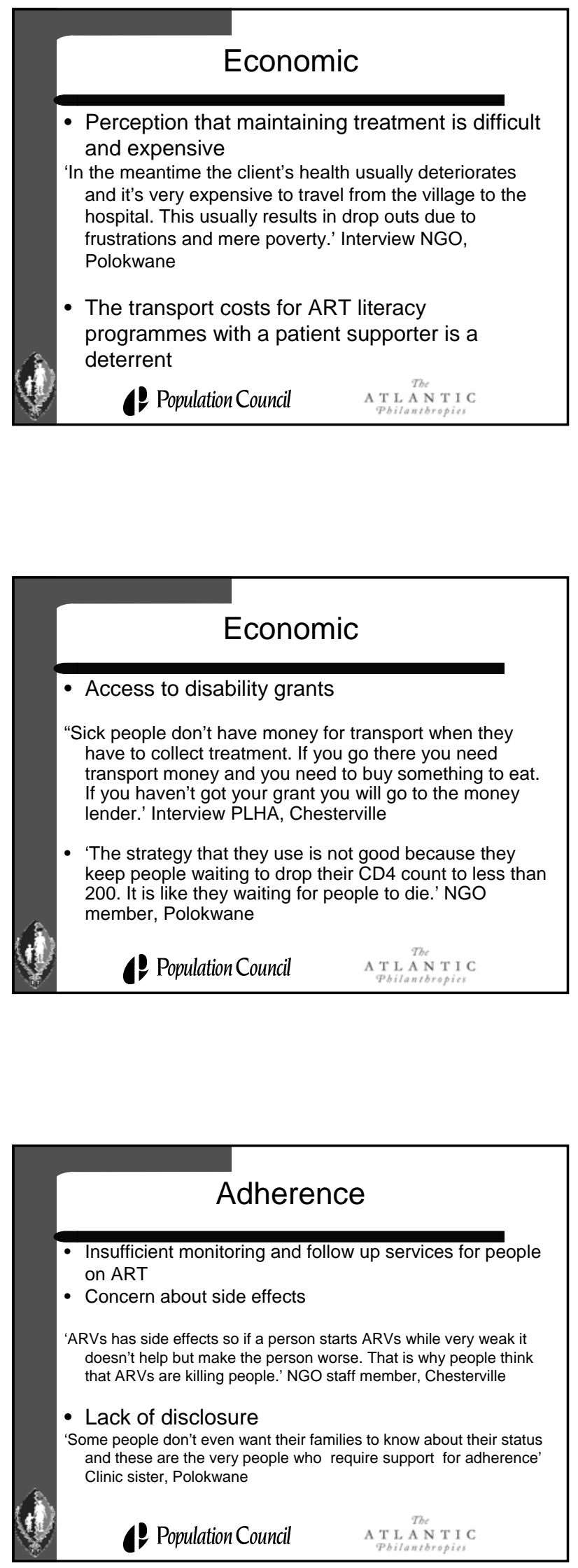

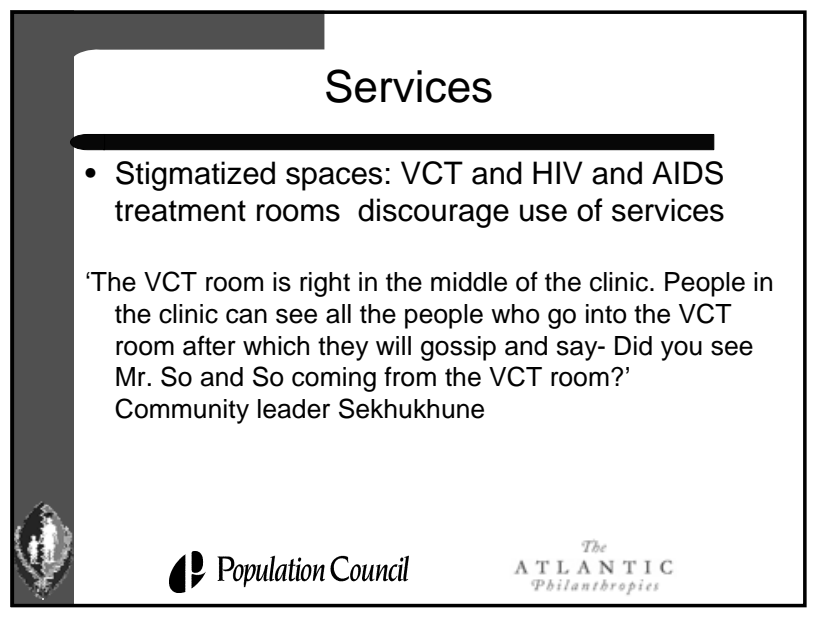

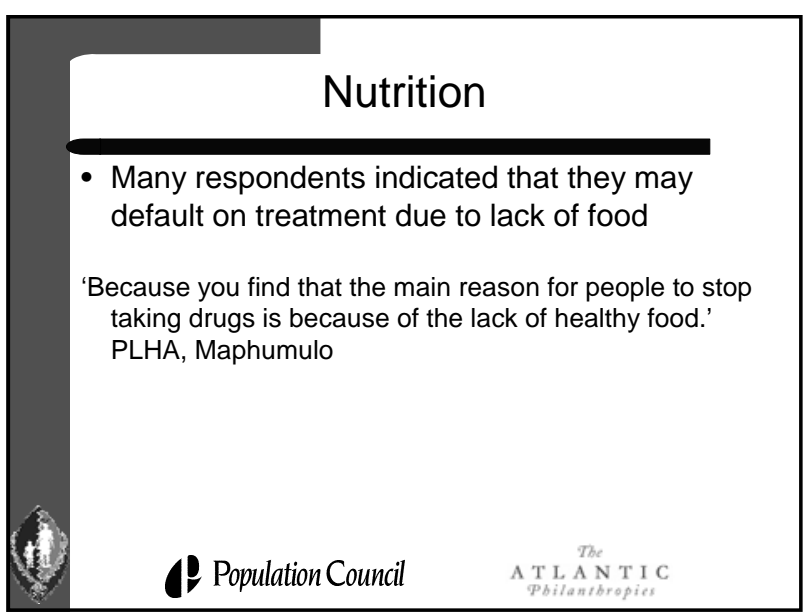




\section{Roles and Capacity of Communities}

- Community participation in HIV and AIDS

- Home based caregivers

- Community Healthcare Workers

- Clinic Committees

- Support Groups

- Participation in ART programs

- Suggested roles

\section{Community Health Workers}

- CHWs are well known in the community

- Many challenges

'I don't have information about NGO's. The only people that I know that they are helping sick people in this community are CHWs'

Reverend, Maphumulo

(1) Population Council A T L A N T I C

\section{Community Participation in HIV and AIDS}

- NGOS/CBOs still focused in providing care and psycho-social support services

Examples of community programs

- Takalani Nana

- Traditional Healers' Organisation

- Operation Hunger

- Mthande Society for the Aged

(Fopulation Council $\underset{\text { A pilantbropies }}{\text { The }}$ Th I C

Clinic Committees
- Vary in their functions
- Diverse perceptions of roles
'The clinic committee is a link between the community and
the clinic and we look at the manner in which nurses
attend to the community and we assist by looking after
people who desperately require assistance'
Clinic Committee Member Polokwane

$\mathbf{P}$ Population Council

\section{Home Based Caregivers}

- Function as an important source of support for PLHA

- Many challenges

'We visit three households per day. We walk long distances as they are far apart from each other... we cover three areas. We are walking maybe three to four kilometers a day.' HBC, Maphumulo

(P) Population Council

\section{Support Groups}

- Support groups are highly stigmatized but are starting to gain popularity

- Serve as an important source of information and psycho-social support for PLHA

'We are trying to form a support group but the problem is HIV positive people are not consistent. Every month when we meet a new group comes and those who attended the previous month drop out' PLHA, Polokwane

(F) Population Council A T L A N T I C 


\section{Participation in ART}

- Need for training in ART issues

- Lack of leadership and support for participation in treatment

- Limited mechanisms for collaboration

- Barriers posed by stigma

(F) Population Council

\section{Suggested Roles: Government}

- Education on HIV, AIDS and ARVs

- Providing nutritional support

- Initiating income generation projects for PLHA

- Facilitating and supporting local community based initiatives

- Decentralising treatment

(F) Population Council

\section{Suggested Roles: Community Members}

- Educating on HIV, AIDS and ARVs

- Promote stigma reduction by PLHA

- Treatment supporters

- Community leaders to facilitate open dialogue about AIDS

(2) Population Council A T T P A N T I C

\section{Suggested Roles: NGOs}

- Treatment literacy

- Treatment support and encouragement to PLHA

- Liaising with Government Departments 
HIGHLIGHTS OF ISSUES \& RECOMMENDATIONS: STRATEGY DEVELOPMENT MEETING, JOBURG

EKA ESU WILLAMS

POPULATION COUNCIL JOHANNESBURG

DURBAN and POLOKWANE, AUGUST 2006

\section{Meeting Approach}

- Setting the scene: Policy perspectives KZN DoH, NDoSD

- Dissemination: Research results

- Community perspectives on results: TAC, NAPWA, MDCI

- Discussion: Identification of key issues

- Group Work: Prioritizing and operationalizing strategies

\section{Objectives}

- Share results of the ART research conducted in Limpopo and KZN Provinces

- Solicit participants’ input in understanding and utilizing the research findings

- Develop key strategies to operationalize findings and to integrate these into treatment, care and support programs

\section{Priority Issues}

- Contextualizing medical model/approach being applied to ART and community participation

- Identify practical, realistic strategies to fully bring on board FBOs, NGOs \& clinic committees

- Addressing the involvement of political leadership at the local level

- Addressing neglected groups and issues: e.g. mixed care, traditional healers, elderly carers

\section{Participation}

- 52 participants from 30 organizations

- Government, research institutions, local and international NGOs, FBOs and CBOs.
- Brain drain, patient-staff ratio, poor health seeking behaviors

- Addressing weak intersectoral collaboration, especially government and NGO collaboration

- Monitoring and evaluation: lack of transparency, problems of accountability, unclear criteria 


\section{Priority Issues \& Needs Identified}

\section{Family}

- What is working:

$\checkmark$ Contributions by informal carers, extended family members

$\checkmark$ Traditional values that expect family members to look after their relatives

$\checkmark$ Commitment to care

\section{NGOs/FBOs/CBOs}

- What is working:

$\checkmark$ CT outside clinical setting

$\checkmark$ Referral to services

$\checkmark$ United platform of patients and families
- What is needed:

$>$ Combating stigma, differentiating between stigma \& depression \& finding effective solutions

$>$ Quality education that is culturally sensitive and tailored to different community groups

$>$ Capacity building and support for carers
- What is Needed:

Institutional body to manage collaboration and coordination

$>$ Well defined mechanisms and support to enable communities to become more involved in ART

$>$ Ways to address exploitation of PLHIV by community groups and leaders because of grants

> Sustainable IGA models for communities

Making well people on ART to become selfsustaining and useful to their communities

\section{Traditional Healers}

- What is working:

$\checkmark$ Providing holistic care, one-on-one counseling for PLHIV

$\checkmark$ THs have established trust with community

$\checkmark$ They do not stigmatize PLHIV

$\checkmark$ Some have been trained by $\mathrm{DoH}$ and form part of hospital treatment team 
- What is needed:

$>$ Reverse barriers, as well as unsubstantiated claims e.g. cure for HIV and AIDS

$>$ Build trust and collaboration among THs; ensure they belong to an association

$>$ Get THs involved in research

$>$ Document and acknowledge THs' contributions to treatment

\section{Policy}

- Issues/Problems:

$\checkmark$ Interface between government and communities confusing

$\checkmark$ Confusing roles, structure, supervision and support re clinic committees

$\checkmark$ Communication and collaboration between clinic staff and community absent or weak

$\checkmark$ Weak referral systems and coordination

$\checkmark$ Poor incentives for carers

\section{Government:}

- What is working:

$\checkmark$ Facilitating HBC

$\checkmark$ Providing social grants

$\checkmark$ Defining criteria for eligibility to treatment

- What is needed:

$>$ Facilitate and support activities to ensure that clinic committees function effectively

$>$ Clarify roles of health workers, NGOs,

CBOs, clinic committees etc in treatment

$>$ Document community experiences, especially effective participation of different players and groups
- What is needed:

$>$ Ensure clarity of roles and responsibilities clinic committees

$>$ Document good practices

$>$ Develop relevant policies and guidelines

\section{DoSD’s Issues}

- Need to come up with a program beyond grants (seen as an interim measure)

- Linking OVC care and support with treatment

- Stepping out of the box in order to become an effective treatment partner 


\section{Follow-up Program \\ Phase 11}

\section{Participants’ Inputs}

- What main themes/areas should we focus on?

- Who should we work with at the community level?

- What should the main strategies be?

- What should be the main outcomes in 2 years?

- What should we NOT do? (i.e.which may be unproductive, amount to duplication of effort)

\section{Objectives}

$\checkmark$ Use research results to design and implement an intervention program

$\checkmark$ Develop community capacity to participate more effectively in treatment

$\checkmark$ Advocate/facilitate the formulation of policies and guidelines to enhance community participation

$\checkmark$ Document good practices and lessons

\section{Elements of proposed interventions}

- Work in 3-4 provinces

- Involve national organizations

- Involve NGOs, FBOs, CBOs, THs, Clinic Committees etc

- Develop community capacity, including in M\&E

- Test and evaluate interventions

- Document and disseminate results

- Advocate for policy formulation 


\section{Dept of Health: KZN}

Presentation by

Dr M.S. Dlwati

Durban 8 August 2006
- Tact, sympathy and understanding are expected of the health care provider for the patient is no mere collection of symptoms, signs, disordered functions, damaged organs and disturbed emotions

- He is human, fearful and hopeful, seeking relief, help and reassurance

\section{Role of health care provider}

- Practice of medicine combines both science and art

- Role of science in medicine is clear

- Combination of medical knowledge, intuition and judgement defines the art of medicine which is necessary to the practice of medicine as is sound scientific base
- A professional attitude coupled with warmth and openness can do much to alleviate patient's parts of their history that may be embarrasing

\section{Core values and objectives}

- DOH is committed to performance and - In the care of the suffering, we need technical skill, scientific knowledge and human understanding

- He who uses these with courage, humility and wisdom will provide a unique service for his fellow man and will build an enduring edifice (structure) of character within himself courage to learn, change and innovate

- Identify challenges and offer solutions for implementation, as well as to improve health care provided in the province in the Province both in the Public and Private sector 


\title{
Report
}

- The results of the study which was done here in KZN and Limpopo provinces will highlight some of the challenges on health service provision as well as roles of community involvement in HIV/AIDS and ARV services

\section{Thank you}

\author{
Siyabonga
}

\section{Challenges}

- DOH has got some challenges to the provision of health services however has accomplished many successes which include improved access and quality of care, as well as implementation of Comprehensive Plan for the prevention, treatment, care and support of HIV/AIDS

\section{Concluding remarks}

- I have no doubt that this presentation will set the tone for the future of health care in our Province, taking into account the objectives of effectiveness and efficiency in the provision of quality, compassionate and equitable health services

- On behalf of DOH-KZN province, we would like to welcome your report as well as recommendations on this study report 
The Comprehensive Plan

for HIV and AIDS

The Rollout of Antiretroviral Therapy

\section{COMMUNITY PARTICIPATION WHO? WHY? HOW?}

8 May 2006

Dr Thilo Govender

KwaZulu-Natal Department of Health

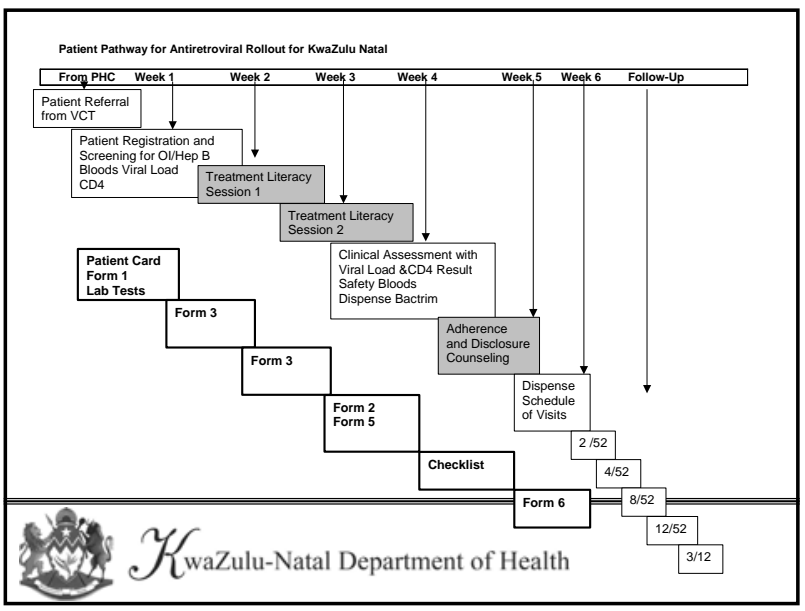

\section{Community Involvement}

- WHO?

- WHY?

- HOW?

\section{The Rollout Programme in KwaZulu Natal}

- Started in March 2004

- 35 Facilities Accredited in Year 1

- 55 Facilities in Year 2

- Currently decanting of patients to Community Health Centers

- 170039 patients screened

- 35430 on treatment

\section{Who is the Community?}

- Geographic: People living in a defined area

- Shared Interest

- Target Populations

- Misnomer that communities are a homogenous entity

YwaZulu-Natal Department of Health 


\section{WHY?}

- Needs Analysis

- Expectations

- Benefits

- Reconcile needs, expectations and health services

\section{Challenges}

- Beyond a Medical Model

- Sustained involvement

- Quality of life

\section{Concluding Message}

- ORGANISE!

- CONSCIENTIZE!

- MOBILIZE!

- Together Each Achieves More

\section{Community Involvement in the} Rollout Program

- Accreditation of Facilities

- Stakeholder Mapping

- Treatment Team

- Continuum of Care

- Mobilizing community resources

- Involvement of traditional healers

\section{Thank You}

Siyabonga

YwwaZulu-Natal Department of Health 


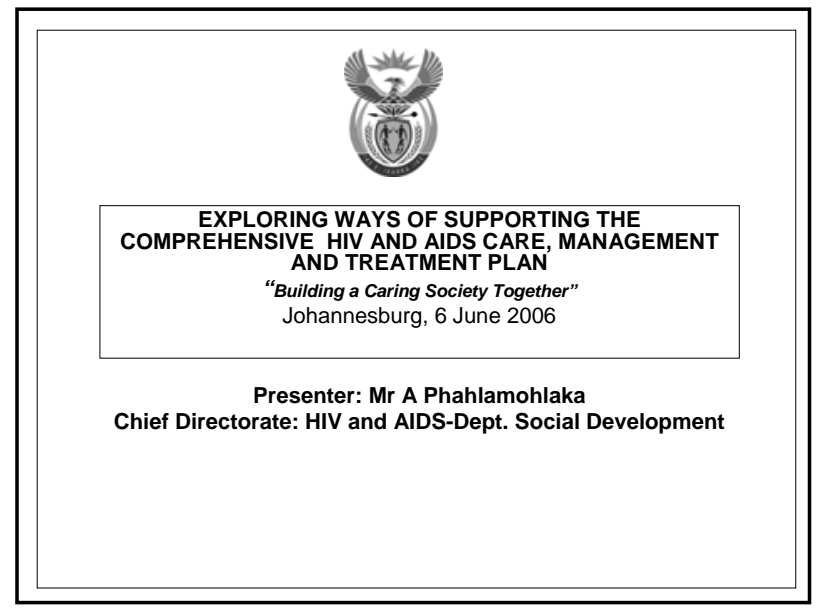

The Policy Framework for Orphans and other children made vulnerable by HIV and AIDS, 2005

- the Policy Framework gives guidance for the protection and provision of comprehensive continuum of care and support

- addresses the value-adding role of various stakeholders in mitigating the socio-economic impact of HIV and AIDS

- interventions guided by the six key strategic areas in the Policy Framework and the National Action Plan

- addresses the value-adding role of various stakeholders in the social impact of HIV and AIDS

\section{Guiding Principles}

- $\quad$ the impact of HIV and AIDS is best understood within the family and community context

coordination between all sectors of society to ensure access to basic services

- service provision should be geared at protecting and promoting human rights

- interventions should seek to strengthen the caring and economic capacities of families (cohesion of the family) through communitybased mechanisms
Strategies: Strengthen and support the capacity of families to support and care for OVC

- mechanisms to provide psychosocial support to families

- sustainable food security systems (nutritional support)

- comprehensive and integrated developmental services for those on ARV and their families

- develop and maintain systems to track HIV+ primary caregivers and ensure they have access to primary health care services

\section{Mobilise and Strengthen Community-Based Responses for care,} support and protection of OVC

- early identification and referral systems

- strengthen social support of people on ARV at community level by linking with local health and other facilities

- actively engage communities in: adherence support and defaulter tracing

- identification of possible candidates for ARV treatment via the community-based care and support programme

\section{Key areas for sector response}

- psychosocial support for people on ARV and their families

- nutritional support (food security)

- expansion and enhancement of Community Based Care and Support programmes

- continued care and support for orphans and vulnerable children and their families 


\section{Key considerations}

- strengthening community responses e.g. communitybased organisations to play a meaningful role in ARV rollout

- prolonging the lives of primary caregivers by expanding treatment

- addressing the needs of the most vulnerable families and communities by ensuring access to basic services

- psychosocial well being of primary caregivers has a direct impact on children

- promote and support interventions that preserve and reinforce family and community cohesion

Key considerations continue......

- successful ARV rollout requires collaboration, integration and strengthening of current initiatives

- a coordinated public policy response is therefore very crucial 


\section{National Strategy Dissemination Meeting, Johannesburg}

June 6, 2006

\section{Presentation by Dr. N. Dinat} Wits University

\section{Two main perspectives on} participation

- Utilitarian

- Uses community resources to offset the cost of service provision

- Empowerment tool

- Service users participate in decision making

\section{Community Participation Background}

- 27 years after Alma Ata Declaration

- Started in the area of health promotion and expanded to other areas such as service delivery

- Complex phenomenon which is evolving

- No detailed conceptual framework for high HIV prevalent settings

\section{Community participation}

- Understanding barriers to community participation in HIV and ART services are key to ensuring successful community participation

- Discuss study findings and recommendations and apply our own experiences and perspectives -

with the aim of developing strategies which may strengthen community participation in HIVIAIDS services

\section{Who or what is community?}

- Defined geographically

- Represent diverse or even opposing interests

- Common interests

- TAC

- Are PLHA's living openly with HIVIAIDS

representative of all PLHA's?

- FBO

- Youth, women ... 


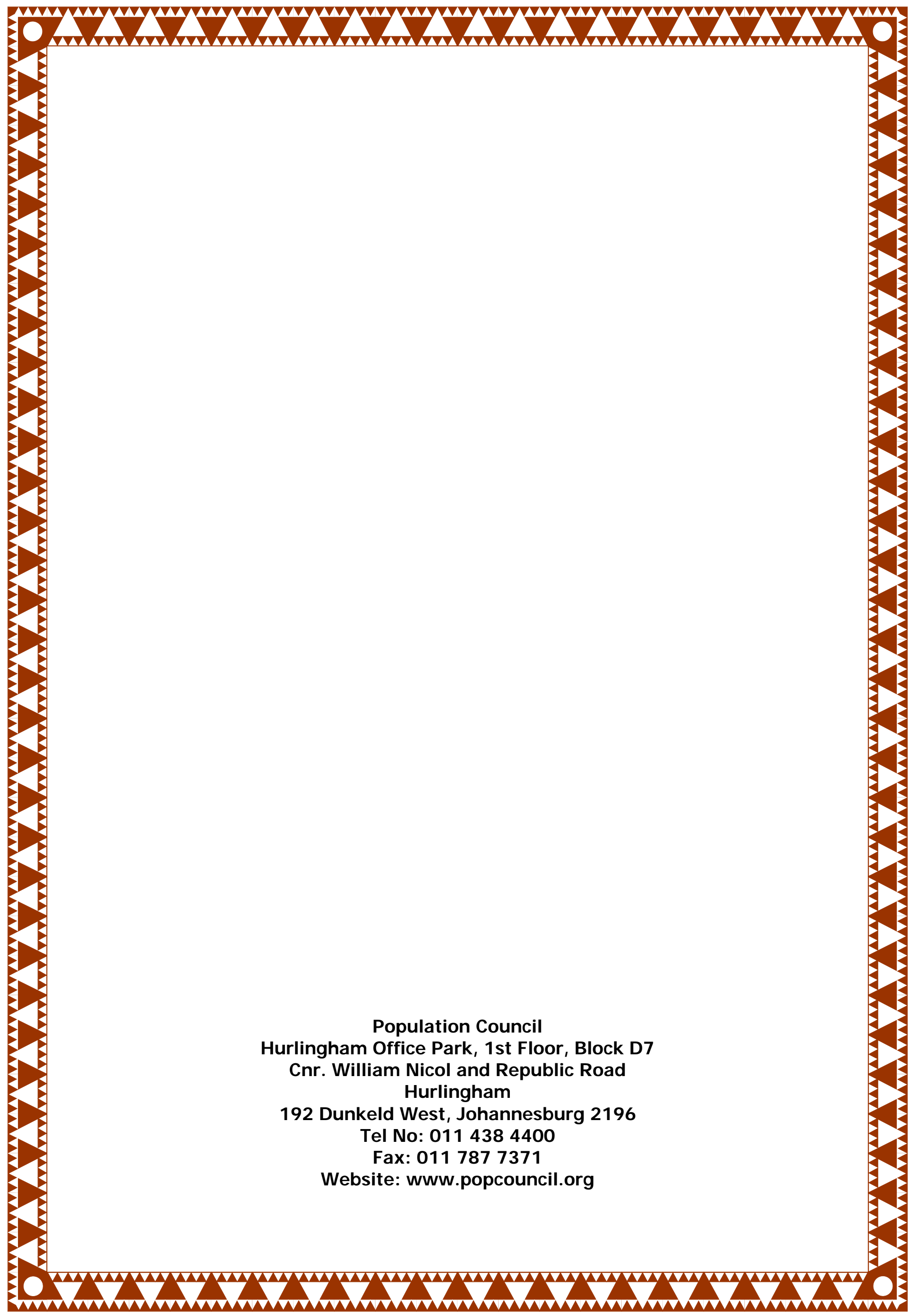

